\title{
WestVirginiaUniversity
}

THE RESEARCH REPOSITORY @ WVU

Graduate Theses, Dissertations, and Problem Reports

2005

\section{Consulting foresters of West Virginia: A profile, services and fees}

Dheeraj Nelli

West Virginia University

Follow this and additional works at: https://researchrepository.wvu.edu/etd

\section{Recommended Citation}

Nelli, Dheeraj, "Consulting foresters of West Virginia: A profile, services and fees" (2005). Graduate Theses, Dissertations, and Problem Reports. 3220.

https://researchrepository.wvu.edu/etd/3220

This Thesis is protected by copyright and/or related rights. It has been brought to you by the The Research Repository @ WVU with permission from the rights-holder(s). You are free to use this Thesis in any way that is permitted by the copyright and related rights legislation that applies to your use. For other uses you must obtain permission from the rights-holder(s) directly, unless additional rights are indicated by a Creative Commons license in the record and/ or on the work itself. This Thesis has been accepted for inclusion in WVU Graduate Theses, Dissertations, and Problem Reports collection by an authorized administrator of The Research Repository @ WVU. For more information, please contact researchrepository@mail.wvu.edu. 


\title{
Consulting Foresters of West Virginia: A Profile, Services and Fees
}

\author{
Dheeraj Nelli
}

Thesis submitted to the College of Agriculture, Forestry and Consumer Sciences at West

Virginia University in partial fulfillments of the requirements for the degree of

\section{Master of Science \\ In \\ Forest Management}

\begin{abstract}
David W. McGill, Ph.D., Chair
Kathryn G. Arano, Ph.D.

Chad D. Pierskalla, Ph.D.
\end{abstract}

Division of College of Agriculture, Forestry and Consumer Sciences Division of Forestry

Morgantown, West Virginia

2005

Keywords: Consulting Foresters, NIPF Landowners, Services, Fees. 


\section{ABSTRACT \\ Consulting Foresters of West Virginia: A Profile, Services and Fees}

\section{Dheeraj Nelli}

Consulting foresters of West Virginia were surveyed with an aim to identify and document the firm characteristics, services offered and fees charged. The survey response rate was 56 percent. A suite of thirty-six (36) different services with different fee structures for each service is reported. West Virginia consulting foresters reported that they most commonly charge by the hour, with an exception for timber sale administration where they charge as a percentage of the sale revenues and for management plan preparation where they charge by the acre. Timber sale administration is the most frequent offered service, with an average fee of 12 percent of the timber sale revenues. Average hourly fees charged for all the services ranged from 30 to 70 dollars per hour. The two major challenges faced by the consulting foresters are cost of doing business and competition. 


\section{Acknowledgements}

I wish to extend my sincere thanks to several individuals who assisted me in successful completion of my project. To begin with, I would like to thank Dr. Dave McGill for providing an opportunity to get into the program and work with him on the project. His strong belief in me made me more enthusiastic and challenging to take up several works and completing them. Under his guidance and supervision I got to learn a lot especially in the United States which is thousands of miles away from my home.

I would also like to thank all the wonderful people in the faculty and staff of West Virginia University and particularly Davis College of Agriculture, Forestry and Consumer Sciences. I consider myself lucky to get an admission in this esteemed University and work with the Division of Forestry. My earnest thanks to my committee members, Dr. Kathryn Arano and Dr. Chad Pierskalla whose assistance helped me a lot for completing this research and faculty of Division of Forestry for aiding me in completing my Master’s degree.

Lastly, I would like to thank all my family members, especially my mom, my dad, my brother, sister-in-law and my younger brother. I would also like to thank my friends here and in my home country, India. 


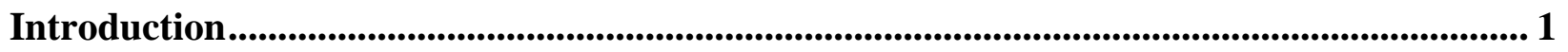

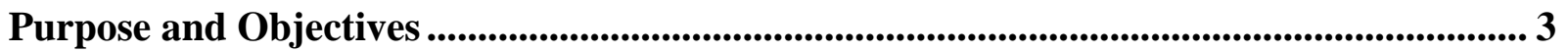

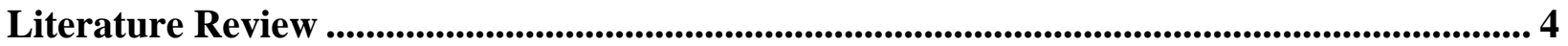

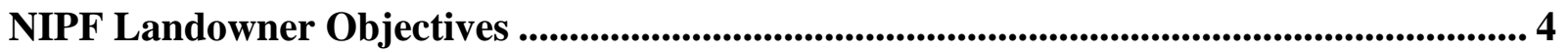

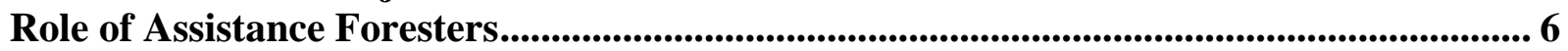

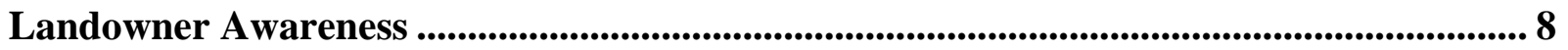

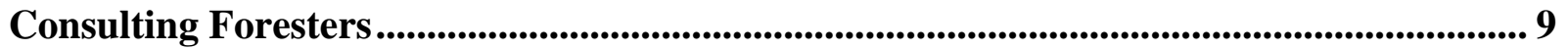

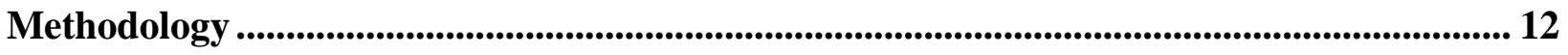

Selection of consulting forestry firms............................................................................................. 12

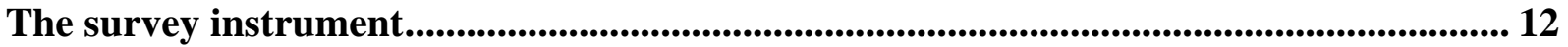

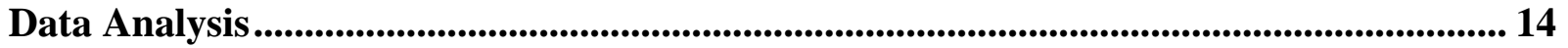

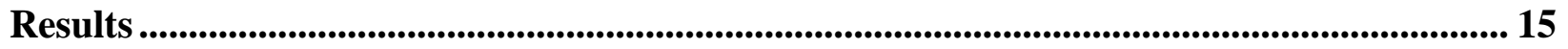

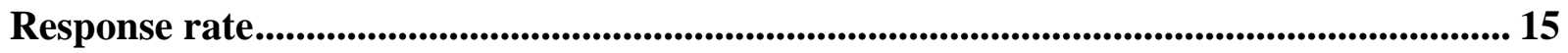

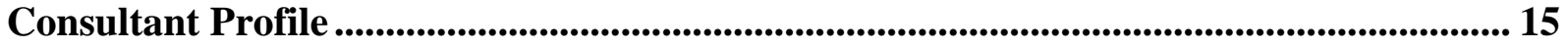

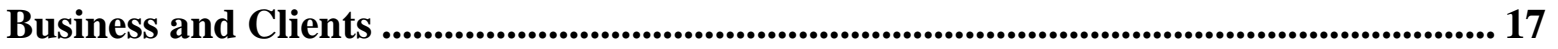

Consultant Work Distribution ........................................................................................... 18

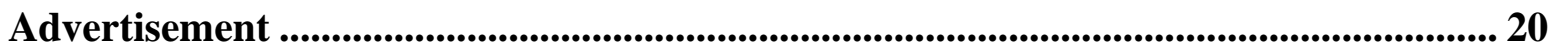

Organizations and Licenses ........................................................................................ 21

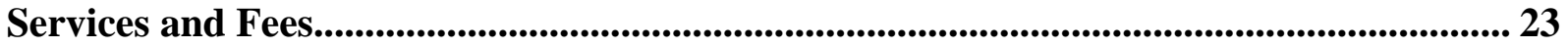

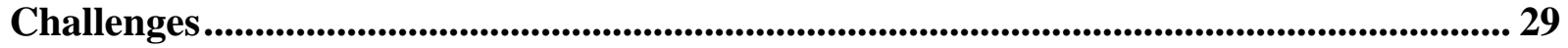

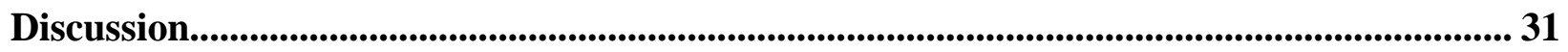

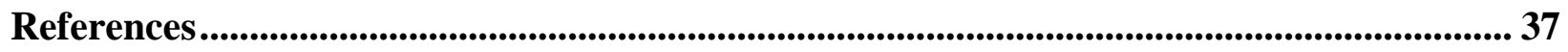

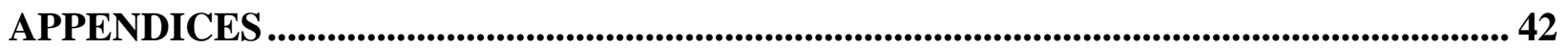

Appendix A: Cover Letters ................................................................................................ 43

Appendix B: Questionnaire.................................................................................................... 46

Appendix C: Fees charged by the consultants for various services in West Virginia,

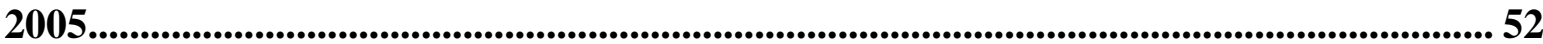




\section{$\underline{\text { List of Tables }}$}

Table 1. Number of foresters and employees of forestry consulting firms in West Virginia, 2005. 16

Table 2. Ownership types for forestry consulting firms in West Virginia, 2005 16

Table 3. Roles/titles of respondents of the forestry consulting firms in West Virginia, 2005 16

Table 4. Consulting work carried out by a firm in and around West Virginia, 2005 .......... 18

Table 5. Percentage of clientele by ownership types of the consulting firms in West Virginia, 2005

Table 6. Willingness to travel of West Virginia consulting foresters to perform a consulting job, 2005.

Table 7. Percentage responses to the mode of advertisement of Consultants in West Virginia, 2005

Table 8. Licenses and certifications of consulting foresters in West Virginia, 2005............. 22

Table 9. Services offered by the Consulting foresters or firms in West Virginia, 2005. ...... 24

Table 10. Fees charged by the consultants for top six services offered in West Virginia, 2005

Table 11. Hourly fees charged for forestry services offered by consulting foresters in WV, 2005.

Table 12. Common Fee Structures for services offered by consulting foresters in WV, 2005. 


\section{List of Figures}

Figure 1: Forestry consulting in West Virginia by County, 2005. ......................................... 20

Figure 2: Distribution of consulting foresters in West Virginia by organizational memberships, 2005........................................................................................................... 22

Figure 3: Distribution of top six services offered by consulting foresters in West Virginia,

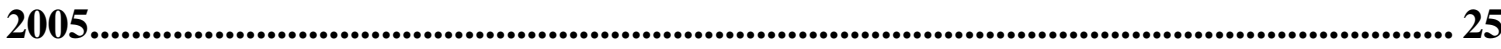

Figure 4: Distribution of fee structures for the six most offered services by consulting

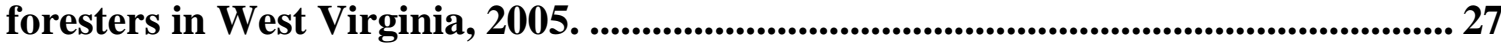




\section{Introduction}

Forests cover 12 million acres in West Virginia or 78\% of the total land area (Griffith and Widmann, 2003). West Virginia ranks third in the nation with respect to percent forest cover just behind Maine and New Hampshire, but exceeds these states in the number of private landowners (Jennings, 2003). Most of this forestland (90\%) is privately owned (McGill et al., 2004 a) with nearly $80 \%$ owned by 260,000 non-industrial private forest (NIPF) landowners (USDA Forest Service, 2004). NIPF landowners are those who own forestland but do not possess or operate wood processing facilities (Bliss et al., 1997).

West Virginia landowners have diverse and multiple objectives for managing their lands (Jennings, 2003) and have a diverse suite of educational and technical assistance needs (Magill 2000; Magill et al., 2004). Forestry technical assistance and education needs are generally provided by natural resources professionals. Specifically, forestry professionals in West Virginia are licensed to denote this specialized area of expertise. Several types of foresters interact with private forest owners and each has different motivations, directives, and services rendered. The major groups of forestry professionals providing technical assistance include public foresters, private foresters, and industry foresters (Zhang et al., 1998). Public foresters, also referred to as service foresters, work for the county, district or state, and are employed usually by the state division of forestry (Westfall, 2001). Foresters who work for the forest industry firms are known as industry foresters while foresters who run their own forestry consulting business are referred to as private foresters (Zhang and Mehmood, 2001). Apart from these three, there are several other categories such as, extension forester, forest ranger, forest supervisor, acquisition forester, and urban forester. Extension forester deals primarily with educational and trainings; forest rangers take care of the National Forests and their duties include fire control, recreational 
activities, thinning and harvesting; a supervisor supervises personnel and administers programs in the forest; acquisition foresters find land for their company to buy; and urban forester maintain healthy urban trees and forests (Monaghan and Londo, 2003).

Professional foresters offer a variety of services to landowners and these services provided may be either free (e.g., public foresters) or with a fee (e.g., private foresters) (Zhang et al., 1998). Foresters providing technical assistance on fee or contract basis and whose services are offered to general public rather than to a single full time employer are referred to as consulting foresters (Kronrad and Albers, 1984). Landowners seeking professional assistance for managing their forestlands are unacquainted with the consulting forester's services and fees. Forestry extension and other forestry outreach organizations recommend that landowners contact professional foresters prior to attempting timber harvesting/marketing or other forest-based activities. However, many private landowners in West Virginia are unaware of the different kinds of services these foresters provide and the fees they charge for each service. While previous studies (Munn and Watkins, 2001; Henly et al., 1990; Hodges and Cubbage, 1986; Kronrad and Albers, 1984, Kronrad et al., 1980; Martin, 1977) have reported the various services offered and fees charged by consulting foresters in other states, there currently exists no comprehensive list of services rendered by consulting foresters in West Virginia nor associated fees charged for those services that might give private forestland owners an idea of the investment of time and money that might be required to carry out these various activities. Thus, this project was conducted to generate a list of forestry services available to West Virginia private forestland owners and to estimate average fees associated with those services. 


\section{Purpose and Objectives}

The main intent of this project was to make known, in a general sense, the suite of services offered by foresters in West Virginia and to provide an idea of how much a private forestland owner might pay for these services. The information on the services and fees allows the landowner to anticipate how much he or she might have to spend to implement a forestry practice on their property with the assistance of a consulting forester.

The overall purpose of this project is to compile a document which illustrates the various services and fees offered by consulting foresters in West Virginia. The specific objectives of this study include:

1. Identify various services offered by the consulting foresters in the state.

2. Document the average fees and range of fees for each service offered.

3. Identify the standard fee structure for the services offered.

4. Depict the characteristics of the consulting forester firm.

5. Identify the current challenges faced by the consulting foresters.

Results from this study will be beneficial to the private landowner when selecting a forester to assist them with forestry practices and to extension agents, service foresters, and other educators who can deliver the information to landowners seeking technical assistance from consulting foresters. 


\section{Literature Review}

\section{NIPF Landowner Objectives}

Forests are considered important natural resources available to mankind. Apart from timber, these forestlands provide numerous amenities such as recreation, aesthetic landscapes, wildlife habitat, clean water and air (Flora, 1992). In West Virginia, millions of acres of forestland are managed by private landowners. Private landowners who own these forests have diverse objectives in managing their property.

The general objectives of the landowners may be based on forest resources like timber, wildlife, recreation and aesthetics or human benefits like income production, long-term investment, and personal satisfaction (McEvoy, 1998).The objectives of the NIPF landowners in West Virginia include timber production, wildlife habitat improvement, prevention of soil erosion, recreation, forest road construction, and improved appearance and water quality (Jennings, 2003). The objectives depend on the location and type of forests, which are discussed below. These objectives differ based on different factors such as available resources, size of the property, occupation of the owner, and available cost-share programs. Some landowners believe that the forest property is similar to any agricultural land and a revenue generating resource. Landowners view trees as any agricultural crop, which are to be harvested and replanted to meet necessities (Bliss, 1993). Usually most landowners managing their land are not dependent of income generated from forests, but, factors like retirement, periodic need of money, and products for personal use drive them to harvest their woods (Bliss and Martin, 1990). But, studies of Jones et al., (1995) and Esseks and Moulton (2000) have shown that timber production is not the primary objective of many NIPF landowners. In spite of several state and federal incentive 
programs, timber production was found lower on the private non-industrial forest (PNIF) lands (Young et al., 1985).

Apart from timber, landowners can make money even from other activities like leasing their lands for hunters. In Alabama, due to low stumpage prices, landowners increased the fees for hunting leases which not only increased the earnings but also improved the wildlife management activities on their lands (Hussain et al., 2004). A study conducted in seven midsouth states showed that environmental protection is high among the NIPF owners in the region (Bliss et al., 1997). Aesthetics and recreation were the prime reasons of owning the forestlands rather than timber production and land investment (Birch, 1996).

In order to take into account the multiple objectives of landowners and attain maximum benefits, proper management plan is essential. To promote forest management on these private forestlands, Congress shaped a Forest Stewardship Program (FSP) as part of the 1990 Farm Bill. The program provides an opportunity for landowners to define their objectives (Egan, 1997). Obtaining a stewardship plan prepared by a professional forester is the first step in the forest stewardship program (Kays and Drohan, 2004).

Landowners with these multiple objectives need appropriate guidance and assistance for management that can be provided by qualified forestry professionals. NIPF landowners are always looking for professional assistance so as to meet their objectives (Bliss et al., 1997). Among the different types of assistance such as financial, workshop and technical assistance, most landowners requested technical assistance (from foresters) (Magill, 2004a). Technical assistance was the second most ranked attribute next to stewardship planning when the landowners of FSP were surveyed (Jennings et al., 2004). 


\section{Role of Assistance Foresters}

In the profession of forestry, a person who has had special education, training and experience is known as a forester (Helms, 2002) and his or her duties include management plan preparation, timber appraisals, timber sale administration, marketing, wildlife habitat improvement, boundary marking, timber stand improvement operations, and aesthetic improvements (Westfall, 2001; Zhang et al., 1998).

The major groups of forestry professionals include public foresters, private foresters and industry foresters. Public foresters, also referred to as service foresters, work for the county, district or state, and are employed usually by the state division of forestry (Westfall, 2001). They generally do not charge for their services if rendered to private landowners. Service foresters play a key role in assisting many forest management activities (McGill et al., 2004; Westfall, 2001) including most of the state forest health programs (Billings, 2000). Industry foresters work for forest industry firms and may or may not charge for their services to the landowners (Zhang et al., 1998). Consulting forester is "a professional... who devotes not less than 75 percent of his working time each year to performing... technical forestry work... on a fee or contract basis” and who offers his services "to general public rather than to single full-time employer (Stuart, 1979).”

Studies in the past have shown that professional foresters play an important role in assisting landowners engaged in forest management. Royer and Kaiser (1985) studied the association between regeneration and professional assistance in southern pine regions, which showed that two-thirds of the regeneration investments accounted for professional assistance as compared to one-eighth without any assistance. Timber management is highly influenced by the assistance of a professional forester (Westfall, 2001; Egan, 1997; O’Hara and Reed, 1991; 
Schenpf and Baumgartner, 1988) and NIPF landowners making timber harvest decisions without the guidance of a professional forester are often prone to damage the site and residual stand (Jones et al., 1995). Significant increase in stumpage prices of aspen was observed with the assistance of a professional forester in Minnesota (Henly et al., 1990).

In some instances, foresters even provide assistance in land surveying, urban forestry and landscaping, Christmas tree production, tax preparation, and legal or other natural resourcerelated matters. Services of these foresters also include forest reconnaissance, management planning, timber marking, forest pest control advice and product marketing and utilization assistance (Bliss and Martin, 1990).

Forest owners who own small parcels of forest lands as a result of fragmentation rarely seek advice from foresters, which is contrasting to landowners who own large parcels of land (DeCoster, 1998). As tract size becomes smaller, the management objectives of the landowners become unclear related to timber production (Olson, 1979). However, landowners of small tracts of forest lands also need assistance from foresters. For example, Gan and Kolison, (1999) have shown that minority landowners (landowners owning about 100 acres) of southeastern Alabama required technical assistance for various forest management activities such as, regeneration, management planning, timber marketing/sales, livestock grazing, fire prevention, wildlife management and disease control.

Foresters get updates regarding changes in tax laws and can help landowners who are concerned about the taxes (Kingsley et al., 1988). In Minnesota, members of Tree Growth Tax Law (TGTL) require landowners to have a management plan in order to be eligible for a lower tax rate (Rathke and Baughman, 1996). 
Proper management of the forestland requires appropriate guidance and assistance, which can be provided by qualified forestry professionals. Changes in NIPF management practices can be brought by both the public sector (i.e., through public foresters) and private sectors (i.e., through personal contact with private forester) (West et al., 1988).

\section{Landowner Awareness}

In order to improve the forests for production and conservation purpose, landowners are always searching for information and professional advice. However, many are not aware of the assistance available to them. Studies in West Virginia showed that about $49 \%$ of the landowners were unaware of whom to contact for forestry assistance (Birch and Kingsley, 1978) and though aware, where not sure from where to get the assistance (Kingsley et al., 1988).

In Pennsylvania, only 10\% of NIPF landowners had written forest management plans and less than $20 \%$ of timber harvesting from them is under the supervision of a professional forester (Jones and Finely, 1993). A great number of landowners in the south, though having multiple objectives do not seek professional assistance and ones seeking assistance may receive it from state agency personnel (Wicker, 2002). Landowners of Alabama did not receive much technical assistance in the past, and they are willing to obtain the consulting foresters' services if they were feasible through grants or loans (Gan et al., 2003). Even motivated landowners find it difficult to obtain technical advice and services (Field, 1986). Landowners’ lack of knowledge in forest management motivates them to seek assistance of a consulting forester (Kronrad et al., 1980). 


\section{Consulting Foresters}

Due to a heavy workload, it is difficult for most Department of Natural Resources (DNR) foresters to spend time to assist and contact all the landowners (Shockley and Martin, 2000). A consulting forester therefore comes into the picture and acts as a catalyst in forest management (Milliken, 1988). Studies conducted nationally show that there is a gradual increase in the number of consulting foresters and acres under their management (Field, 1986).

Among different groups of foresters, consulting foresters contribute about $50 \%$ of the assistance offered to NIPF landowners and show active participation while assisting these landowners (Zhang et al., 1998). They are also involved in writing the FSP plans. A five-year evaluation of the program in WV showed that about $62 \%$ of the plans were written by consulting foresters (Egan et al., 2001) and a ten-year evaluation showed that about 50\% of the FSP plans were written by consulting foresters (Jennings, 2003). In Georgia, most of the forest management decisions were influenced by consulting firms (Hodges and Cubbage, 1986). In southern pines, consulting foresters advised most of the landowners than public or industry foresters during regeneration decisions (Royer and Kaiser, 1985).

Landowners seek assistance of the consulting foresters who work on a fee or contract basis. The major clients of consulting foresters tend to own 100 to 500 acres. Landowners owning 400 acres or more receive assistance from consulting foresters (Royer and Kaiser, 1985). Wealthier clients are more likely from the South Central and Pacific Southwest regions in the United States (Field, 1986).

The fee structure or method of payment for these consulting foresters depends on the nature of the work. Typically, fees are charged on a per acre basis, hourly basis, daily basis, or percent of the sale revenues (Kronrad and Albers, 1984). The most common fee structure 
adopted is on an hourly basis or daily basis. Standard hourly and daily fees are observed in all cases with means ranging from $\$ 45$ to $\$ 50$ per hour and $\$ 250$ to $\$ 300$ per day (Munn and Watkins, 2001). For services like timber sale administration, charges are based on a percent of the sale revenues. Kronrad et al., (1980), reported that the average percent for timber sale in Massachusetts was 12 percent, with a range from 10 to 15 percent. Timber sale administration in North Carolina had a mean of 8.3 percent (Kronrad and Albers, 1984) and Mississippi had a mean ranging from 7.75 percent to 8.55 percent depending on the tract size (Munn and Watkins, 2001). Activities like management plan preparation, regeneration, and prescribed burning are charged a fee on a per acre basis. Study of Munn and Watkins (2001) showed that the average fees for preparing management plans ranged from $\$ 5.00$ to $\$ 6.00$ per acre. Consulting forester fees are considered as expenditures in forest management. A study of Mississippi NIPF landowners showed that the consulting forester's fees were the third largest expenditure following property taxes and planting costs (Arano et al., 2002).

Consulting foresters are members of professional organizations and these are indicators of their professional acceptance and commitment (Kronrad and Albers, 1984). Most of them are certified and members of different professional organizations like Society of American Foresters (SAF), Association of Consulting Foresters (ACF), and other forestry associations. A study conducted in Pacific Northwest showed that 70\% were members of SAF, 27\% were members of ACF, and approximately 39\% were members of American Forestry Association (Schenpf and Baumgartner, 1988). Members of ACF follow the code of ethics while practicing forestry. Competition exists in every profession and consulting foresters always had a problem of competition from other assistance foresters like public service foresters, industry foresters and sometimes even other consulting foresters (Field, 1986). 
Apart from these studies that have investigated fees and services of the consulting

foresters, little has been done in West Virginia. This project will fill a void by documenting the status of fees and services rendered by West Virginia foresters in this earliest period of the $21^{\text {st }}$ century. 


\section{Methodology}

A mailed survey questionnaire was used to identify the services offered and fees charged by consulting foresters in West Virginia. The development of the target population of foresters was developed simultaneously with the survey instrument.

\section{Selection of consulting forestry firms}

All the consulting foresters or firms included in the Appalachian Hardwood Center (AHC) website (2005) and Directory of Forestry- Related Professionals (2005) were selected as the population for the survey. The database consisted of 127 consulting foresters or firms. West Virginia Division of Forestry Service Foresters and other groups of natural resource professionals such as extension foresters, wildlife specialists, wood scientists and other forestry related professionals who do not charge fees for the technical assistance services they offer were excluded from the database.

\section{The survey instrument}

The survey instrument (See Appendix B) used in this study was a mailed questionnaire and was patterned after a similar study conducted by Munn and Watkins (2001). Foresters or firms not offering forestry services were separated from others with a question that inquired whether they offer forestry services and were asked to return the questionnaire if they did not. Other questions were formulated to characterize the makeup of the forestry consulting firms in the state such as, number of clients engaged, type of clients, mode of advertisement, counties where most of the work is concentrated, willingness to travel, ownership type served, number of 
employees, professional organizations, professional licenses and certifications, number of years in business, and the two biggest challenges they face.

Tables were used in the questionnaire to characterize the range of services and fees (Appendix B). These tables provided a list of services in rows with answer blanks for the various methods of payments (fee structures) in columns. The columns listing the common modes of payments included: dollars/acre, dollars/hour, dollars/day, percent of sale revenues and others (if any). The tables also included columns where the respondents could indicate the average number of jobs and average acreage of a particular service that their firms provided in an average year. A column for general comments was also provided.

Data for this project was collected using Dillman’s tailored design method (Dillman, 2000). Questionnaire mailings were made to the selected foresters in the following manner beginning in the second week of July 2005:

1. The first mailing in the second week of July, 2005 included the five-page questionnaire and a cover letter (Appendix A), stating the need for the study and requesting their participation.

2. After two weeks a reminder letter (Appendix A) was sent to the all the participants, thanking them for their participation and requesting the non-respondents to complete the survey and return the questionnaire.

3. A month later, in the second week of August, 2005, a follow-up mailing including a questionnaire (Appendix B) to was sent to all the non-respondents to improve response rates. 
Return postage was provided in both the first and second questionnaire mailings to increase the response rate. Cover letters contained a confidentiality statement. All return envelopes were coded to decrease the number of unnecessary mailings.

\section{Data Analysis}

Data from returned questionnaires were entered in MS Excel along with the mailing code for each respondent. Of the total respondents who answered the questionnaire, a few did not answer each and every question. So number of responses received for each individual question was recorded (n) separately. Summary statistics were computed for each question.

Arc GIS 9.0 was used to evaluate where the respondents render their services. A shape file of the West Virginia counties with a scale of 1:24000 was downloaded from the West Virginia GIS Technical Center (2005) and added to Arc GIS 9.0. An attribute with number of foresters working in each county was added to the county attribute table. A natural break classification was used and eight classes were created based on the number of consulting foresters working in each county.

Content analysis (Weber, 1990) was used to analyze the responses for the question, "What are the two biggest challenges faced by the company?” Nine major categories were developed for these open-ended questions and each response was assigned to one of the categories. Initially 20 sub-categories were developed which were collapsed into 9 nine major categories and only a couple of them had responses which had more than one category. 


\section{Results}

\section{Response rate}

The total population for initial mailings included 127 consulting foresters. Two surveys were returned with insufficient addresses. Thus, the final population for the survey consisted of 125 consulting foresters or firms. Seventy questionnaires were returned resulting in a response rate of 56 percent. Of the seventy respondents, 17 did not offer any forestry services. Sixteen of them quoted the reason that they were either retired or no longer practice forestry. One respondent is a timber investment and management organization (TIMO) which engages consulting firms to manage their investment properties.

Fifty-three respondents offered forestry services, of which, three respondents offered services in the neighboring states of West Virginia like Maryland, Virginia and Pennsylvania and did not complete the questionnaire. Therefore fifty survey responses were used in the survey summaries.

\section{Consultant Profile}

Forestry consulting firms in West Virginia employed an average of two (2) foresters, with a maximum of 7 and a minimum of 1 (Table 1). However, most the firms (64\%) had only one forester who is a full time employee. The average number of employees working for these firms was four (4), ranging from 0 to 43 (Table 1). Only one firm reported having 43 employees, all others had 12 or less. The majority (63\%) of the firms had only one employee suggesting that the average is skewed by an extreme value; the median number of employees was one.

Forty-nine responded to the question pertaining to ownership types. The majority (56\%) were sole proprietors, followed by corporations (13\%), LLCs (9\%) and partnerships (1\%; Table 
2). Most respondents (45\%) were owners of their firms. A lesser number had titles like consulting forester, forester, president and vice president (Table 3).

Table 1. Number of foresters and employees of forestry consulting firms in West Virginia, 2005

$\begin{array}{lllll}\text { Foresters/ Employees } & \mathrm{n}^{1} & \text { Mean } & \text { Min. Max. }\end{array}$

No. of Foresters working in the firm 45

2

1

7

No. of Employees working

46

4

0

43

${ }^{1}$ - Number of responses for each question.

Table 2. Ownership types for forestry consulting firms in West Virginia, 2005

\begin{tabular}{lcc}
\hline \multicolumn{1}{c}{ Ownership type } & Frequency & Percent \\
\hline Sole Proprietorship & 28 & 56 \\
Corporation & 13 & 26 \\
Limited Liability Company (LLC) & 9 & 18 \\
Partnership & 1 & 2 \\
\hline
\end{tabular}

Note: Percentages were based on $n=49$ and do not total 100 due to multiple responses.

Table 3. Roles/titles of respondents of the forestry consulting firms in West Virginia, 2005

\begin{tabular}{lcc}
\hline \multicolumn{1}{c}{ Role/Title } & Frequency & Percent \\
\hline Owner & 21 & 45 \\
Consulting Forester/ Consultant & 12 & 26 \\
Forester & 12 & 26 \\
President & 7 & 15 \\
Vice-President & 2 & 4 \\
Director of Operations WV & 1 & 2 \\
Forest Technician & 1 & 2 \\
\hline
\end{tabular}

Note: Percents were based on $n=47$ and do not total 100 due to multiple responses. 


\section{Business and Clients}

Forty-seven respondents said that they had been engaged in forestry business from 3 years to 50 years, with a median of 15 years and mean of 19 years (Table 4). The minimum acreage requirement for a firm to consider a consulting job ranged from 1 acre to 250 acres. Although the mean acreage was 22 acres and median acreage was 10 acres (Table 4). Few respondents (5) said that there is no set requirement and one respondent quoted that money (min. \$1000) was the criteria and not acreage.

The average number clients engaged each year is 39, with a minimum of 2 and maximum of 300 (Table 4). However, the median number of clients for these firms is 20 and only $10 \%$ of the firms work with more than 100 clients in a given year. West Virginia consulting firms provide about 20 hours per month of pro-bono services (for example, free information, advice, or visitations to a landowner before implementation of any practice). The average number of hours of pro bono services per forester works out to be about 15 hours per month. Forty-seven responded to the percentage of client types for their consulting business. On an average $48 \%$ of the clients were small NIPF landowners (owning less than 100 acres; Table 5). However 31\% of the client types were large NIPF landowners (owning greater than or equal to 100 acres). Others included industry (7\%), other investors (5\%), trust/estates (3\%), government (3\%) and financial institutions (2\%). 
Table 4. Consulting work carried out by a firm in and around West Virginia, 2005

\begin{tabular}{lccccc}
\hline \multicolumn{1}{c}{ Clients/ Consultant Work } & $\mathrm{n}^{1}$ & Mean & Median & Min. & Max. \\
\hline Years in Business & 47 & 19 & 15 & 3 & 50 \\
Minimum acreage requirement & 46 & 22 & 10 & 1 & 250 \\
No. of Clients engaged each year & 47 & 39 & 18 & 2 & 300 \\
Pro-Bono work (hrs/month) & 49 & 20 & 15 & 0 & 80 \\
\hline
\end{tabular}

1 - Number of responses for each question.

Table 5. Percentage of clientele by ownership types of the consulting firms in West Virginia, 2005

\begin{tabular}{lccc}
\hline \multicolumn{1}{c}{ Type of Clients } & Min.\% & Mean \% & Max. \% \\
\hline Small NIPFs (<100 acres) & 0 & 48 & 100 \\
Large NIPFs (>=100 acres) & 0 & 31 & 95 \\
Industry & 0 & 7 & 50 \\
Other Investors & 0 & 5 & 50 \\
Trust/ Estates & 0 & 3 & 25 \\
Government & 0 & 3 & 90 \\
Financial Institutions & 0 & 2 & 30 \\
Other & 0 & 1 & 20 \\
\hline
\end{tabular}

Included was a question concerning liability insurance policy for the forestry business. Half of the respondents (50\%) did not have any liability insurance policy. But, $44 \%$ of the respondents had some kind of liability insurance policy for their businesses.

\section{Consultant Work Distribution}

Consulting foresters travel around the State to offer their services to different clients. Of the 47 consulting foresters who responded, 33 are willing to travel from 30 to 500 miles and 14 
are willing to travel within 1 to 6 hours (Table 6). On average consulting foresters are willing to travel 142 miles or 2.5 hours from their office.

Table 6. Willingness to travel of West Virginia consulting foresters to perform a consulting job, 2005

Travel $\quad \mathrm{n}^{1} \quad$ Min. $\quad$ Mean $\quad$ Max.

Willingness to travel (MILES)

33

30

142

500

Willingness to travel (HOURS)

14

$1 \quad 2.5$

6

${ }_{1}$ - Number of responses for each question.

To identify the counties in the state where most of the forestry consulting work is conducted, a question was framed asking them to list three counties in WV where most of their work is conducted. Forty nine (49) respondents responded to this question and we received a wide range of responses. Forestry consulting work occurred in 45 counties out of the 55 counties in the state. Of these, most consultants $(n=8)$ worked in Hardy County, followed by Greenbrier ( $n=6)$, Hampshire ( $n=6)$, Randolph $(n=6)$, Braxton $(n=5)$, Monroe $(n=5)$, and Roane ( $n=5$; Figure 1). 


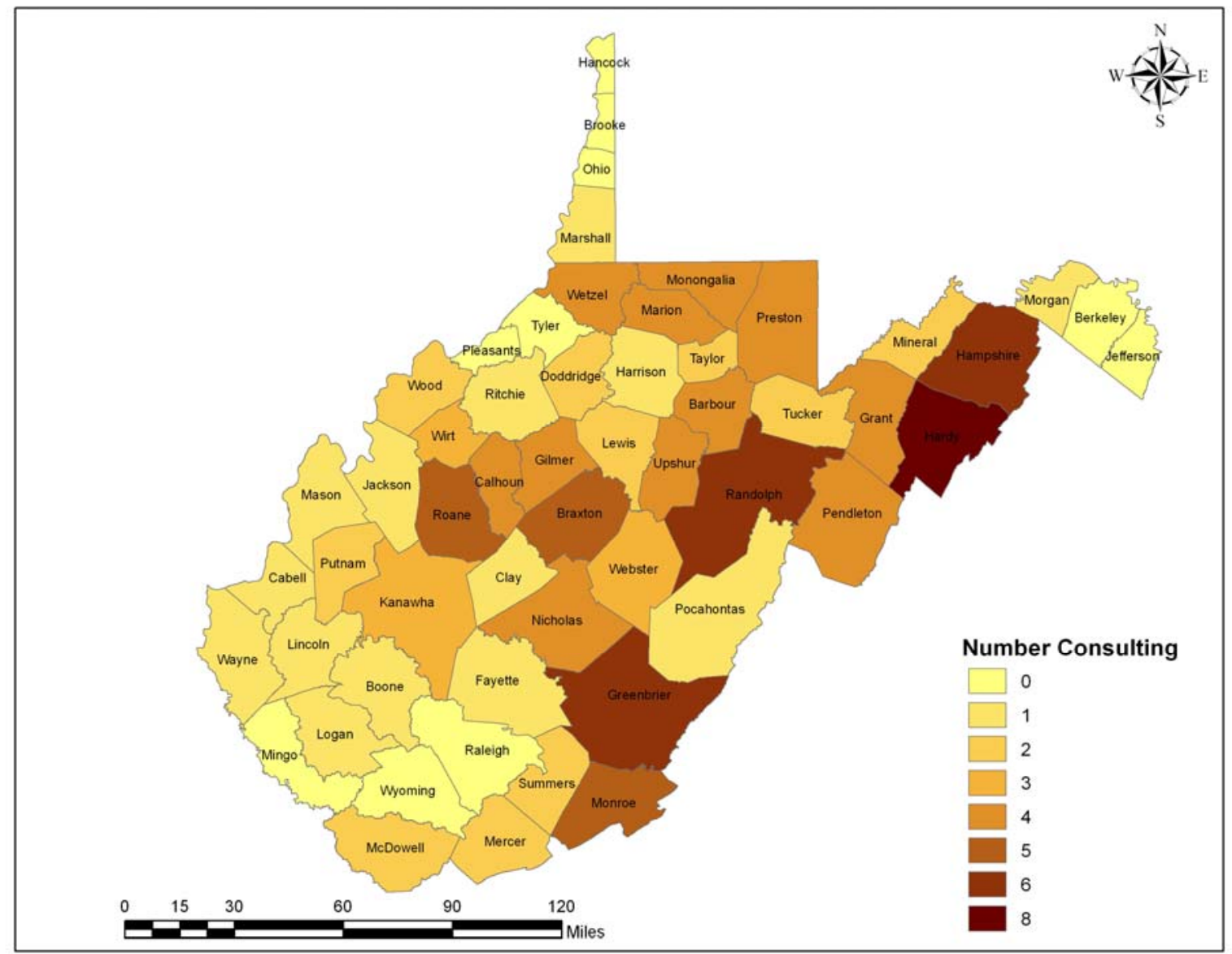

Figure 1: Forestry consulting in West Virginia by County, 2005.

\section{Advertisement}

Included was a question pertaining to the advertisement of the firm, to which forty nine foresters responded. The mode of advertisement with highest mean (83\%) was referrals (Table 7). The most common or frequent value observed for referrals was 100 percent. Thirteen percent responded saying that they had other modes of advertisement such as, internet, direct mail and repeat business. Only 2 percent advertised through yellow pages, 1 percent through posters and 
billboards, 1 percent through newspaper ads, and 1 percent through pamphlets. Of the 47 respondents, none advertised through radio or television ads.

Table 7. Percentage responses to the mode of advertisement of Consultants in West Virginia, 2005

\begin{tabular}{lccc}
\hline \multicolumn{1}{c}{ Mode of Advertisement } & Min.\% & Mean \% & Max. \% \\
\hline Referrals & 0 & 83 & 100 \\
Others ${ }^{\text {a }}$ (Internet, Direct mail, Repeat business) & 0 & 13 & 100 \\
Yellow Pages & 0 & 2 & 30 \\
Posters/Billboards & 0 & 1 & 50 \\
Newspaper ads & 0 & 1 & 20 \\
Pamphlets & 0 & 1 & 20 \\
Radio/ TV ads & - & - & - \\
\hline
\end{tabular}

${ }^{\mathrm{a}}$ - Others were filled in by the respondents.

\section{Organizations and Licenses}

Distribution of consulting foresters by professional organizational membership shows that 48 percent are members of Society of American Foresters (SAF) and 27 percent are members of Association of Consulting Foresters (ACF; Figure 2). Thirty-nine (39) percent of the respondents were members of West Virginia Forestry Association (WVFA). Other organizations included, Woodland Owner Association (WOA; 9\%), Virginia Forestry Association (VFA; 9\%), Ohio Forestry Association (OFA; 7\%), International Society of Arboriculture (ISA; 2\%), and West Virginia Association of Realtors (WVAR; 2\%). Seventy-six percent (76\%) of the consulting foresters are licensed WV foresters and about 15\% had out-of-state licenses. A small percent (27\%) percent had a SAF certified forester license. Others (21\%) had licenses like real estate appraisers or agents, tree farm inspectors (Table 8). 


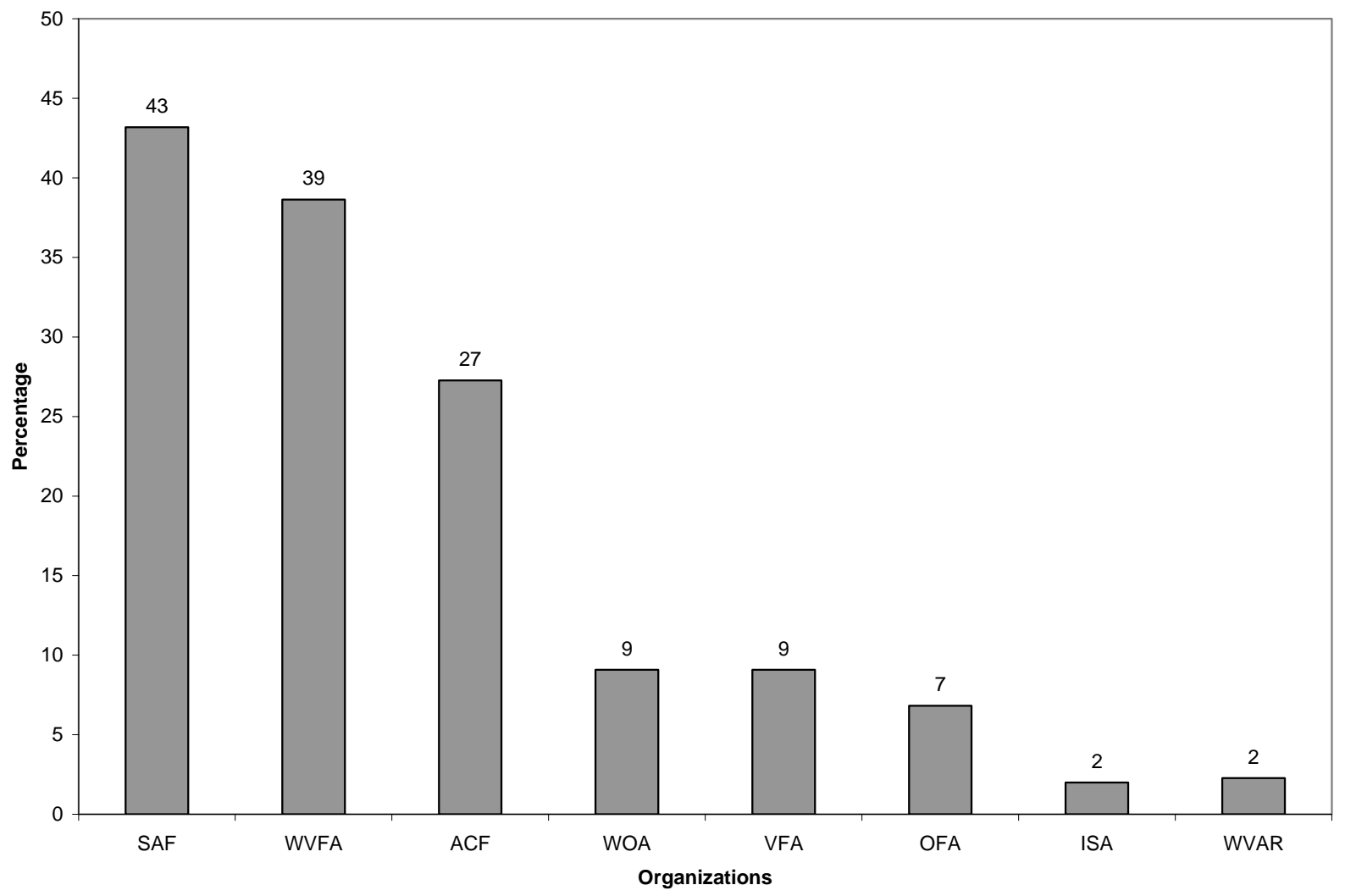

Figure 2: Distribution of consulting foresters in West Virginia by organizational memberships, 2005.

Table 8. Licenses and certifications of consulting foresters in West Virginia, 2005

\begin{tabular}{lcc}
\hline \multicolumn{1}{c}{ Licenses/ Certifications } & Frequency & Percent \\
\hline West Virginia Registered Foresters & 26 & 76 \\
SAF certified forester (CF) & 9 & 27 \\
Out of State License & 5 & 15 \\
Others (Real estate, tree farm, etc.) & 7 & 21 \\
\hline Note: Percentages were based on $n=34$ and do not total to 100 due to multiple responses.
\end{tabular}

Note: Percentages were based on $n=34$ and do not total to 100 due to multiple responses. 


\section{Services and Fees}

Services offered by the consulting foresters can be categorized under forest management, timber sale administration, timber stand improvement, and miscellaneous. But, for this study thirty-six different kinds of services were identified and tabulated in the questionnaire (Table 9; Appendix B). Some respondents included services like invasive plant analysis, timber marketing, gas well site approval, hardwood lumber inspection, timber damage and oil/ gas development, routine property visits for absentee landowners and oil and gas environmental consulting in the others category. The number and percentage of responses for each service offered are reported in Table 9.

Based on the percentage of responses, services offered by more than 50 percent of the consulting foresters who responded were sorted out which include six (6) services. The top six services include timber appraisals, timber sale administration, timber inventory and cruising, expert witness testimony, and forest management plans and timber damage/ trespass appraisals

(Figure 3). For each of those services, the average fees charged along with the most common fee structures used are tabulated (Table 10). Although fees with different methods of payment are reported for only six services in Table 10, a detailed description of all the fees and services based on different fee structures is shown in Appendix C. 
Table 9. Services offered by the Consulting foresters or firms in West Virginia, 2005.

\begin{tabular}{|c|c|c|}
\hline Services Offered & $\mathrm{n}^{1}$ & Percent \\
\hline Accident Investigation & 6 & 12 \\
\hline Boundary Maintenance & 19 & 38 \\
\hline Database Management & 6 & 12 \\
\hline Environmental Assessments & 9 & 18 \\
\hline Expert Witness Testimony & 31 & 62 \\
\hline Financial Analysis & 11 & 22 \\
\hline Forest Management Plans & 31 & 62 \\
\hline Forest Pest and Disease Inspection & 12 & 24 \\
\hline Forest Stewardship (Cost share) Plans & 21 & 42 \\
\hline Forest Tax Consulting & 9 & 18 \\
\hline GIS and Mapping & 11 & 22 \\
\hline Growth and Yield Modeling & 8 & 16 \\
\hline Harvest scheduling and analysis & 14 & 28 \\
\hline Hunting lease Administration & 10 & 20 \\
\hline Land Sales & 11 & 22 \\
\hline Land Surveying & 4 & 8 \\
\hline Log Check Scaling & 6 & 12 \\
\hline Log Marketing & 6 & 12 \\
\hline Log Procurement & 2 & 4 \\
\hline NTFP Assessments and Management & 4 & 8 \\
\hline Prescribed Burning & 2 & 4 \\
\hline Real Estate Appraisals & 11 & 22 \\
\hline Reclamation of Logging Disturbances & 6 & 12 \\
\hline Reforestation (site prep/tree planting) & 4 & 8 \\
\hline Road Design/Layout & 18 & 36 \\
\hline Safety Seminars & 2 & 4 \\
\hline Soils Mapping & 4 & 8 \\
\hline Third Party Audits & 4 & 8 \\
\hline Timberland Acquisition & 13 & 26 \\
\hline Timber Appraisals & 39 & 78 \\
\hline Timber Damage/Trespass Appraisals & 31 & 62 \\
\hline Timber Inventory and Cruising & 33 & 66 \\
\hline Timber Sale Administration & 39 & 78 \\
\hline Timber Stand Improvement & 10 & 20 \\
\hline Urban Forestry Arboriculture & 0 & 0 \\
\hline Wildlife Habitat Improvement & 8 & 16 \\
\hline \multicolumn{3}{|l|}{ Others $^{2}$} \\
\hline Invasive plant Analysis & 1 & 2 \\
\hline Timber Marketing (Hired out) & 1 & 2 \\
\hline Gas well site approval & 1 & 2 \\
\hline HW lumber inspection & 1 & 2 \\
\hline Timber damage and oil/gas development & 1 & 2 \\
\hline Routine property visits (absentee) & 1 & 2 \\
\hline Oil and gas environmental consulting & 1 & 2 \\
\hline
\end{tabular}

${ }^{1}$ Number of consultants who offer the service

${ }^{2}$ Others were filled in by the respondents 


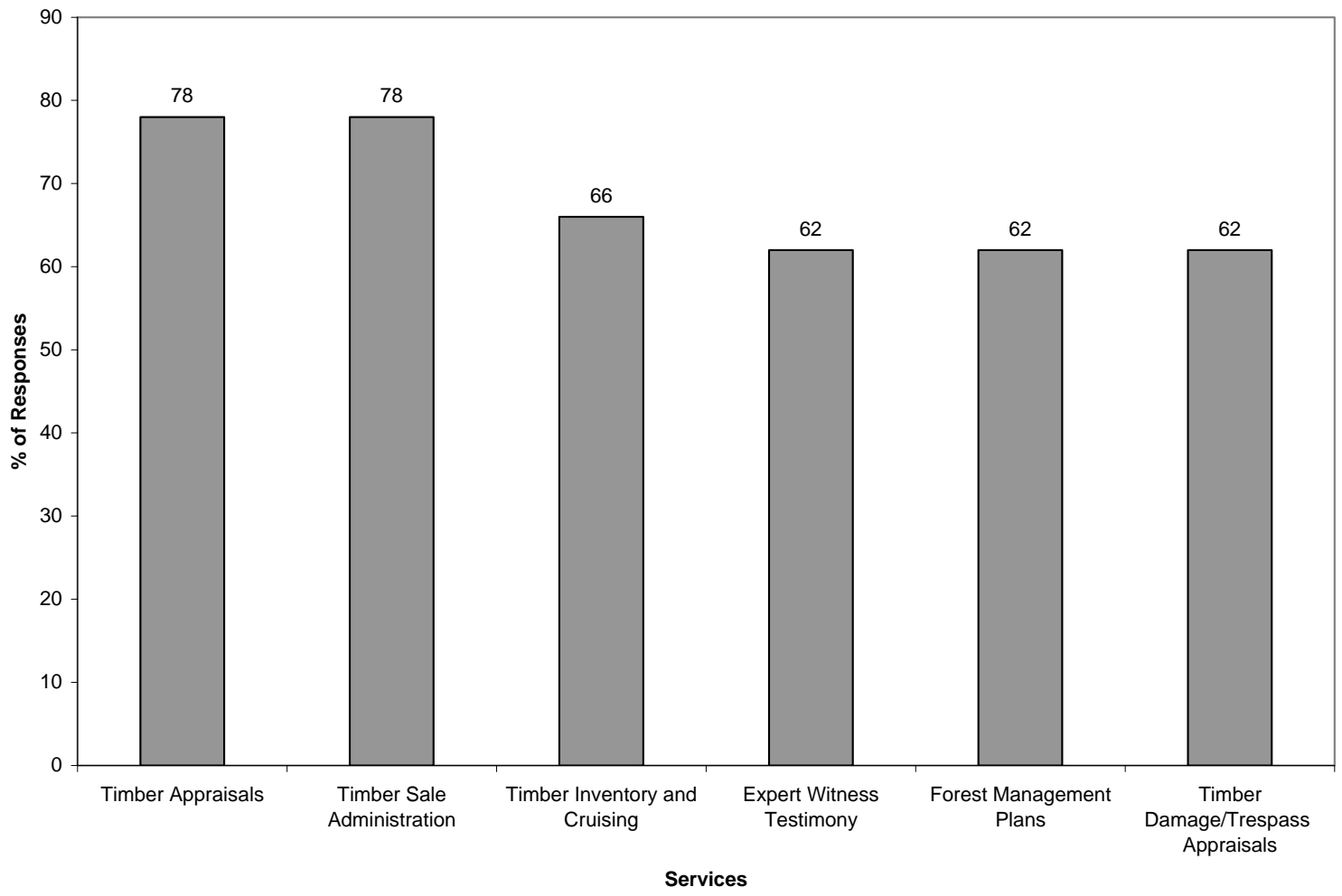

Figure 3: Distribution of top six services offered by consulting foresters in West Virginia, 2005. 
Table 10. Fees charged by the consultants for top six services offered in West Virginia, 2005.

\begin{tabular}{|c|c|c|c|c|c|}
\hline Services Offered & $n^{1}$ & Unit & Min. & Mean & Max. \\
\hline \multirow[t]{4}{*}{ Timber Appraisals } & 5 & \$/acre & 5 & 5.90 & 7 \\
\hline & 20 & \$/hour & 20 & 44.50 & 80 \\
\hline & 13 & \$/day & 200 & 338.46 & 640 \\
\hline & 8 & $\%$ of Sale & 1 & 10.75 & 20 \\
\hline \multirow[t]{3}{*}{ Timber Sale Administration } & 10 & $\$ /$ hour & 20 & 45.50 & 80 \\
\hline & 4 & \$/day & 240 & 387.50 & 640 \\
\hline & 35 & $\%$ of Sale & 8 & 11.71 & 30 \\
\hline \multirow[t]{3}{*}{ Timber Inventory and Cruising } & 5 & \$/acre & 3 & 4.80 & 6 \\
\hline & 16 & \$/hour & 20 & 42.50 & 70 \\
\hline & 13 & \$/day & 150 & 296.92 & 450 \\
\hline \multirow[t]{2}{*}{ Expert Witness Testimony } & 25 & $\$ /$ hour & 20 & 72.00 & 200 \\
\hline & 8 & $\$ /$ day & 250 & 430.00 & 640 \\
\hline \multirow[t]{3}{*}{ Forest Management Plans } & 12 & \$/acre & 4.75 & 6.07 & 7.00 \\
\hline & 14 & \$/hour & 20 & 37.86 & 60 \\
\hline & 9 & \$/day & 200 & 315.56 & 480 \\
\hline \multirow[t]{3}{*}{ Timber Damage/Trespass Appraisals } & 23 & $\$$ /hour & 20 & 48.04 & 125 \\
\hline & 9 & \$/day & 240 & 328.89 & 500 \\
\hline & 5 & $\%$ of Sale & 1 & 4.8 & 10 \\
\hline
\end{tabular}

1 - Number of consultants offering the service.

The most commonly used methods of payment (units) for forestry services include \$/acre, \$/hour, \$/day and \% Sales. Figure 4 shows the distribution of fee structures with regards to each service offered, for the top six ranked services. All the services had one or more than one fee structure, but, $\$$ / hour and $\$$ /day were the most common fee structure for the six services. Timber sale administration, however, was most commonly charged as a percentage of sale revenues.

From the entire data (Appendix C), it clearly shows that the most common fee 
structure or method of payment used by consultants is dollar per hour. The $\$ /$ hour fees (averages and ranges) were sorted out for each service (Table 11). This table gives a clear picture of how much each service costs on an hourly basis. The services are sorted based on the maximum average dollar per hour fees for each service. The most common fee structure or method of payment used for services like timber sale administration is percentage of sale revenues and for services like forest stewardship plans is dollar per acre (Table 12).

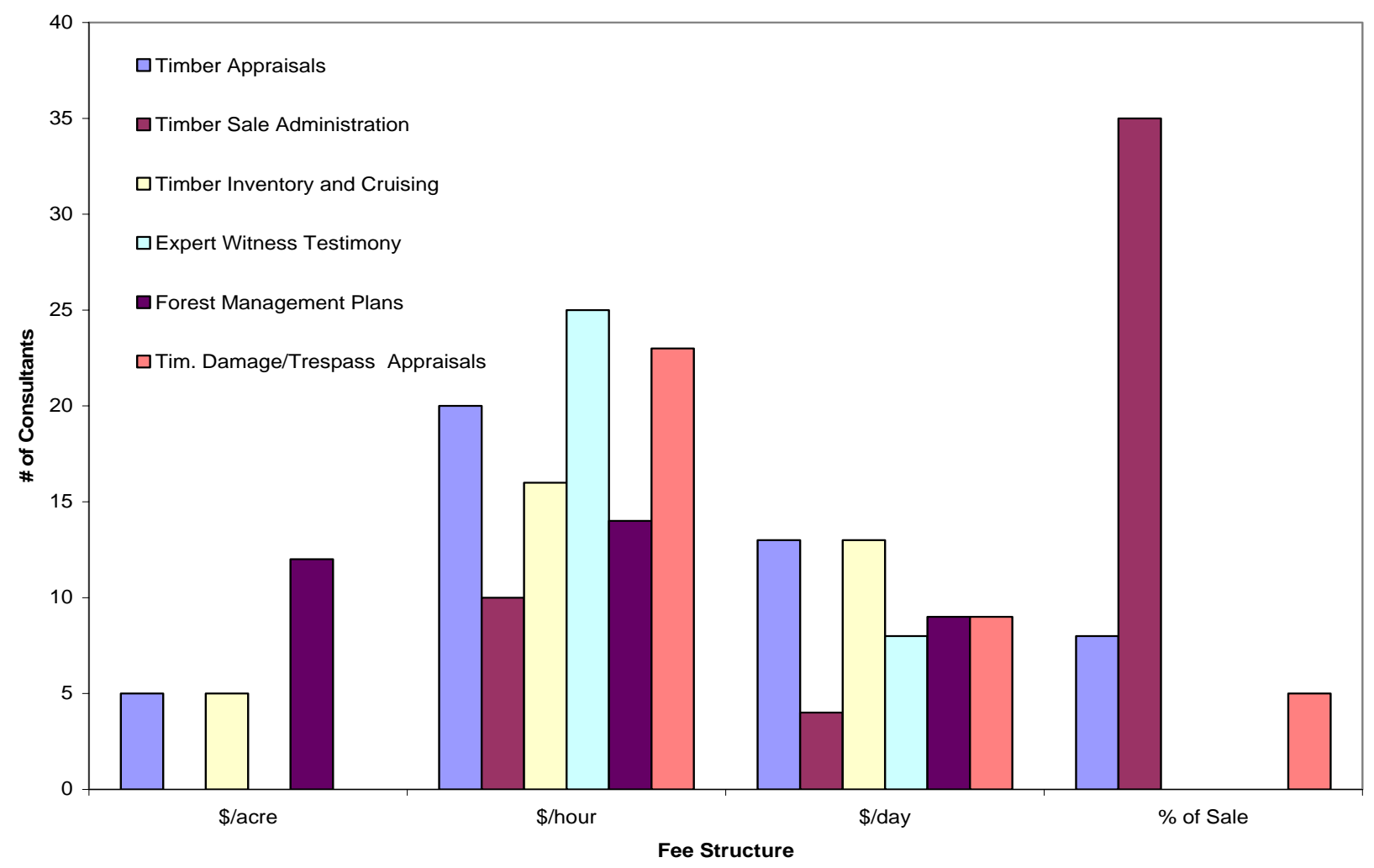

Figure 4: Distribution of fee structures for the six most offered services by consulting foresters in West Virginia, 2005. 
Table 11. Hourly fees charged for forestry services offered by consulting foresters in West Virginia, 2005.

\begin{tabular}{|c|c|c|c|c|}
\hline Services Offered & $\mathrm{n}^{1}$ & Min. \$/hr & Mean $\$ / \mathrm{hr}$ & Max. \$/hr \\
\hline Expert Witness Testimony & 25 & 20 & 72.00 & 200 \\
\hline Land Surveying & 3 & 50 & 68.33 & 80 \\
\hline Accident Investigation & 6 & 20 & 64.17 & 125 \\
\hline Real Estate Appraisals & 9 & 20 & 59.44 & 100 \\
\hline Safety Seminars & 3 & 40 & 53.33 & 70 \\
\hline Financial Analysis & 8 & 20 & 50.63 & 100 \\
\hline Log Check Scaling & 6 & 40 & 48.33 & 60 \\
\hline Timber Damage/Trespass Appraisals & 23 & 20 & 48.04 & 125 \\
\hline Prescribed Burning & 2 & 45 & 47.50 & 50 \\
\hline GIS and Mapping & 9 & 20 & 46.67 & 75 \\
\hline Timberland Acquisition & 10 & 25 & 46.50 & 80 \\
\hline Forest Tax Consulting & 7 & 20 & 45.71 & 60 \\
\hline Growth and Yield Modeling & 7 & 20 & 45.71 & 60 \\
\hline Road Design/Layout & 13 & 20 & 45.38 & 100 \\
\hline Boundary Maintenance & 15 & 20 & 45.20 & 100 \\
\hline Log Procurement & 2 & 40 & 45.00 & 50 \\
\hline Timber Appraisals & 20 & 20 & 44.50 & 80 \\
\hline Third Party Audits & 4 & 40 & 43.75 & 50 \\
\hline Log Marketing & 5 & 40 & 43.00 & 50 \\
\hline Forest Pest and Disease Inspection & 9 & 20 & 42.78 & 70 \\
\hline Database Management & 6 & 20 & 42.50 & 70 \\
\hline Reforestation (site prep/tree planting) & 2 & 40 & 42.50 & 45 \\
\hline Timber Inventory and Cruising & 16 & 20 & 42.50 & 70 \\
\hline Environmental Assessments & 7 & 20 & 42.14 & 80 \\
\hline Harvest scheduling and analysis & 10 & 20 & 41.50 & 75 \\
\hline Land Sales & 5 & 20 & 40.00 & 50 \\
\hline Timber Stand Improvement & 6 & 20 & 40.00 & 70 \\
\hline Hunting lease Administration & 8 & 5 & 38.75 & 60 \\
\hline Soils Mapping & 4 & 30 & 38.75 & 50 \\
\hline Forest Management Plans & 14 & 20 & 37.86 & 60 \\
\hline Reclamation of Logging Disturbances & 4 & 30 & 37.50 & 50 \\
\hline NTFP Assessments and Management & 3 & 20 & 36.70 & 50 \\
\hline Wildlife Habitat Improvement & 4 & 20 & 33.75 & 45 \\
\hline $\begin{array}{l}\text { Urban Forestry Arboriculture } \\
\text { Others }^{2}\end{array}$ & 0 & - & - & - \\
\hline Gas well site approval & 1 & - & 45.00 & - \\
\hline Oil and gas environmental consulting & 1 & - & 30.00 & - \\
\hline Routine property visits (absentee) & 1 & - & 30.00 & - \\
\hline Timber damage and oil/gas development & 1 & - & 30.00 & - \\
\hline
\end{tabular}

${ }^{\mathrm{T}}$ Number of Consultants charging by dollar per hour.

${ }^{2}$ Others were filled in by the respondents. 
Table 12. Common Fee Structures for services offered by consulting foresters in West Virginia, 2005.

\begin{tabular}{lcccc}
\hline \multicolumn{1}{c}{ Services Offered } & $\mathrm{n}^{1}$ & Min. & Mean & Max. \\
\hline Timber Sale Administration & $35(\%$ Sale) & 8 & 11.71 & 30 \\
Forest Stewardship (Cost share) Plans & $15(\$ /$ acre $)$ & 4 & 5.47 & 7 \\
Others $^{2}$ & & & & \\
Invasive plant Analysis & 1 (\$/day) & - & 350.00 & - \\
Timber Marketing (Hired out) & 1 (\$/day) & - & 150.00 & - \\
HW lumber inspection & $1(\$ /$ day $)$ & - & 240.00 & - \\
\hline
\end{tabular}

${ }^{1}$ Number of Consultants with respective fee structures.

${ }^{2}$ Others were filled in by the respondents.

\section{Challenges}

To identify the problems or challenges of the consulting foresters, an open ended question was asked "What are the two biggest challenges facing your company today?” About 46 respondents answered this question focusing on major current issues. Nine major categories developed include cost of doing business, competition, employees, employment, forest management, awareness/ people, markets, environmental laws and regulations/ politics, and health problems.

The two major current challenges faced by the consultants are cost of doing business (41\%) and competition (36\%). Other challenges include employees (26\%), forest management (24\%), environmental laws and regulations and politics (15\%), employment (13\%), awareness and people (13\%), markets (13\%), and health problems (4\%).

Consulting foresters facing problems in cost of doing business are mostly related to taxes, health insurance, fuel and transportation cost, getting paid by landowners and even advertising. Consulting foresters usually compete with service foresters, industry procurement foresters, moon-lighters and even "pin-hookers" (Individuals who buy something with an intension of re- 
selling it at a profit). Employee issues include, finding qualified professionals, lack of cooperation, loggers and logging jobs. Clear cutting, fragmentation, deforestation, landowner's poor management skills and even whitetail deer fall under forest management. Others include politics (red tape), time and work load, poor depressed lumber markets, awareness of general public regarding the forestry consultants, and even issues of health such as age. 


\section{Discussion}

Consulting foresters are an important group of professional foresters providing technical assistance to the private non-industrial forest landowners. They offer a wide variety of services related to forest management and timber sales and charge certain amount of fees for each service. The fee structure for each service depends on the nature of the job. A profile of consultants, services they offer and fees they charge for each service in West Virginia is documented in this study. This information on services and fees allows the landowner to anticipate how much he or she has to spend for implementing a practice on his or her property with the assistance of a consulting forester. Several studies (Henly et al., 1990; Hodges and Cubbage, 1986; Kronrad and Albers, 1984; Kronrad et al., 1980) have been conducted in the past regarding the consulting forester fees during that period. The results show some similarity and dissimilarity with the previous studies and the most recent study conducted in Mississippi (Munn and Watkins, 2001), which are discussed below.

In West Virginia, most of the consulting forestry businesses (56\%) are under sole proprietorship with very few corporations or partnerships. Typically consulting forestry firm in West Virginia is unincorporated and has only one owner (45\%). National survey of consultants showed that 68 percent of the consulting foresters are sole proprietors (Field, 1986). About 50 percent of the consulting foresters were sole proprietors in Georgia and Mississippi, (Hodges and Cubbage, 1986; Munn and Watkins, 2001). The average firm size is small with at least one full time forester and one employee. Employees were either part time or seasonal and some firms had up to 12 employees. Similar kind of organizational structure was shown by a national survey in which firms in the Northern U.S. had no assisting full time personnel and only three seasonal employees (Martin, 1977). Consulting foresters have been engaged in the business of forestry 
from 3 to 50 years with an average of 15 years. Average consulting years of Mississippi consultants was slightly more than 14 years (Munn and Watkins, 2001). The number of clients engaged per year by these foresters range from 2 to 300 with an average of 39 and majority of them are small NIPF landowners with less than 100 acres of land. Other client types include large NIPF landowners with more than 100 acres, other investors, industry, government, trust/ estates, and financial institutions (Table 5). On an average $48 \%$ of the clients of the consultants are small NIPFs and 31\% are large NIPFs. In Alabama, most of the clients of consulting foresters own 100 to 500 acres or more, whereas landowners owning less than 100 acres are clients of public and industrial foresters (Zhang et al., 1998).

Issues discussed in this study such as minimum acreage requirement to consider a consulting job and the hours of pro-bono work per month are new. Most of the consultants had some minimum acreage requirement ranging from 1 to 250 acres. The average set acreage requirement is 10 acres which includes most of the small NIPFs. Although for few there is no set acreage requirement. To these landowners, they offer few hours of pro-bono work which averages to about 20 hours per month. Willingness to travel to get a consulting job done shows the dedication of the foresters towards consulting. Consulting foresters are willing to travel from 30 to 500 miles or 1 to 6 hours away from their office (Table 6). Gas price, which increases the transportation cost, is one of the constraints cited by few consulting foresters in the challenges section. Only forty four percent of the consulting foresters had some kind of liability insurance policy for their consulting businesses. Expensive insurance policies do not provide an incentive for the foresters to get liability insurance.

In forestry consulting business, consultants are usually referred to their clients (landowners) by other landowners, state-service foresters, industry foresters and sometimes even 
other consulting foresters (Field, 1986). In this study, consulting foresters received their business mostly through referrals (83\%). Recently due to vast spread of information through internet, most landowners are obtaining the information about the consulting foresters either from individual, state or even university websites. But, still techniques like posters/billboards, yellow pages, newspapers, and pamphlets are in practice. However, from the responses we received, none advertised through radios and televisions.

Consulting foresters are licensed professional foresters and all the respondents who answered the question had some kind license. On an average they had at least two licenses. Most of them (76\%) were WV registered foresters and a few were SAF certified (27\%). Fifteen percent of them had out-of-State license which is less compared to 44 percent out-of-state licenses in Mississippi (Munn and Watkins, 2001). There are several organizations of which most consulting foresters are members such as Society of American Foresters (SAF), Association of Consulting Foresters (ACF), State forestry associations, Woodland Owner Association (WOA) etc. Membership in these organizations shows us the professional acceptance and commitment of the forester (Kronrad and Albers, 1984). This study reveals that 43 percent of the consulting foresters are members of SAF as compared to 61 percent in Mississippi (Munn and Watkins, 2001), 51 percent in Georgia (Hodges and Cubbage, 1986) and 89 percent nationally (Martin, 1977). Twenty-seven percent are members of ACF and 39 percent are members of West Virginia Forestry Association (WVFA). In Mississippi, 24 percent are members of ACF and 69 percent members of Mississippi Forestry Association (MFA; Munn and Watkins, 2001). Other memberships included Ohio Forestry Association (OFA), Virginia Forestry Association (VFA), and Woodland Owner Association (WOA; Figure 2). 
As quoted by Kronrad and Albers (1984), “consulting forester's livelihood is dependant on satisfied clients," hence, they offer a variety of services related to forest management, timber management and several other forestry related services. Services offered begin from management plan preparation to timber harvesting and sales. With enough knowledge in aspects like tax consulting, financial analysis, land sales, and real estate appraisals, they can assist landowners. Services offered by more than fifty percent of the consulting foresters surveyed include timber sale administration, timber appraisals, timber inventory and cruising, expert witness testimony, and forest management plans and timber damage/ trespass appraisals. This shows that $2 / 3^{\text {rd }}$ of the services offered by more than fifty percent of the consultants are related to timber management.

Landowners usually seek the assistance of consulting foresters for timber sales. Seventy eight percent of the foresters surveyed provide timber sale administration. Timber sale administration is a combination of several other services like boundary maintenance, management plan preparation, GIS and mapping, harvesting scheduling and analysis, reforestation, timber inventory and cruising, and wildlife habitat improvement. Consultants charge a flat fee of the timber sales in terms of percent sale revenues. Ninety percent of the foresters providing timber sale administration have the fee structure of percent sale, which ranges from 8 to 30 percent. The average fee for this service is 12 percent which is slightly higher than that of the Mississippi consulting foresters which rounds to 9 percent (Munn and Watkins, 2001). On the other hand a timber appraisal which is also offered by seventy eight percent of the foresters surveyed is charged mostly on hourly basis. The average hourly fee for timber appraisal is $\$ 44.50$. 
Forest Stewardship plans preparation is one of the services which are commonly charged on dollar per acre basis. The standard plan rates are $\$ 375.00$ plus $\$ 4.75$ per forested acre, of which the landowner get $75 \%$ reimbursement from the state. The data shows us that the range for writing a stewardship plan is $\$ 4.00$ to $\$ 7.00$, with a mean of $\$ 5.47$ (Table 12 ).

Although we find different fee structures for each service, data obtained reveals that the common fee structure used is dollar per hour. Expert witness testimony, offered by $62 \%$ of the consulting foresters has the maximum average $\$$ /hour fee which was $\$ 72.00$ / hour (Table 11). Services like financial analysis, safety seminars, real estate appraisals, accident investigation and land surveying are charged on an average $\$ 50.00$ to $\$ 70.00$. About twenty one services have average fees ranging from $\$ 40.00$ to $\$ 50.00$ (Table 11). Very few services such as hunting lease administration, soil mapping, forest management plans, reclamation of logging disturbances, NTFP assessments and management and wildlife habitat improvement have average fees less than $\$ 40.00$. It is clear from this that if a landowner need assistance regarding a specific service, he or she has to invest on an average from about $\$ 30.00$ to $\$ 70.00$ an hour. These ranges vary from the study of Munn and Watkins (2001) for different services; a few services are charged more or less in Mississippi as compared to West Virginia.

Fees charged by Mississippi consulting foresters for owners owning less than 100 acres can be compared with West Virginia consulting foresters. The average fees for few services in Mississippi (MS) and West Virginia (WV) are discussed below. Management plan preparation is charged 5.83 dollars/acre in MS and 6.07 dollars/acre in WV. Boundary maintenance is charged \$ 45.20 per hour in WV and \$ 31.00 per hour in MS. Hunting lease administration is charged \$ 43.44 per hour in MS and \$ 38.75 per hour in WV. Forest tax consulting is charged \$ 63.75 per hour in MS and \$ 45.71 per hour in WV. Expert witness testimony is charged \$ 72.00 per hour in 
WV and \$ 64.64 per hour in MS. From these examples cited above, we can see differences in fees in both the states.

As discussed earlier, most of the services charged on hourly basis are also carried out during timber sale administration; landowner need not spend separately on each service. During timber sales landowners are given an option for fee structure i.e., either percent of sales or hourly or daily basis. One advantage of selecting percent sales is that the consulting foresters have a vested interest in generating maximum income.

In accomplishing to satisfy private non-industrial forest landowners by offering a variety of services, these foresters face many challenges. The major challenges faced by the consulting foresters are cost of doing business and competition. With heavy taxes, health insurance, and transportation costs, it becomes difficult for a forester or firm to get the consulting job done. Competition with other foresters is an age old issue and is even shown from this study. Competitors of consulting foresters include public service foresters, industry foresters and even other forestry consultants (Field, 1986). Consultants experience competition from service foresters, industry foresters, and moon-lighters. Other challenges include employees and employment, time and work load, public awareness regarding forest management and consultant services.

This information should be propagated to all the NIPF landowners and professional foresters. Detailed study of other professional foresters is essential considering their demographics, consulting relationships, perceptions. Further assessment of differences in fees, perceptions, and general landowner relationships to better define their roles in serving private forest owners is required. 


\section{References}

Appalachian Harwood Center website (2005): http://ahc.caf.wvu.edu/foresters/index.asp

Arano. K.G., Cushing, T.L., and Munn, I.A. 2002. Forest Management Expenses of Mississippi's NIPF Landowners. Southern Journal of Applied Forestry. 26(2):93-98.

Billings, R.F. 2000. State Forest Health Programs: A Survey of State Foresters. Journal of Forestry. 98(1): 20-25.

Birch, T.W. 1996. Private Forest Landowners of the United States (1994). USDA Forest Service, Northeastern Forest Experiment Station, Research Bulletin. NE-134. 183p.

Birch, T. W., and Kingsley, N.P. 1978. The forest-land owners of West Virginia. USDA Forest Service resource Bulletin. NE-58.76p.

Bliss, J.C., Nepal, S., Brooks, Jr., R., and Larsen, M.D. 1997. In the mainstream: Environmental attitudes of Mid-South forest owners. Southern Journal of Applied Forestry 21(1):37-43.

Bliss, J.C. 1993. Alabama's non-industrial private forest owners: Snapshots from a family album. Auburn, AL: Auburn University. Alabama Cooperative Extension Service Center.

Bliss, J.C., Martin, A. 1990. How tree farmers view management incentives. Journal of Forestry 88(8):23-42.

DeCoster, L.A. 1998. The Boom in Forest Owners - A Bust for Forestry? Journal of Forestry 96(5): $25-28$

Dillman, D. 2000. Mail and Internet Surveys, The Tailored Design Method. John Wiley \& Sons, Inc., New York, New York.

Directory of Forestry- Related Professionals, 2005. Appalachian Harwood Center, Division of Forestry, West Virginia University. 80p.

Egan, A., Gibson, D., \& Whipkey, R. (2001). Evaluating the effectiveness of the forest stewardship program in West Virginia. Journal of Forestry, 99(3): 31-36.

Egan, A.F., Rowe, J., Peterson, D., and Philippi, G. 1997. West Virginia Tree Farmers and Consulting Foresters: A comparison of views on timber harvesting. Northern Journal of Applied Forestry. 14(1): 16-19.

Egan, A. 1997. From timber to forests and people: A view of non industrial private forest research. Northern Journal of Applied Forestry 14(4):189-93. 
Esseks, D. and Moulton, R., 2000. Evaluating the Forest Stewardship Program Through a National Survey of Participating Forest Land Owners. Center for Governmental Studies, DeKalb, Illinois.

Field, D.B. 1986. Consulting Foresters. Expanding the business of selling forestry to private landowners. Journal of forestry 84(2): 25-29.

Flora, C.B. 1992. Rural Communities Legacy and Change. Boulder, Colorado. West View Press.

Gan, J., Kolison, Jr., S.H., and Tackie, N.O. 2003. African-American Forestland Owners in Alabama’s Black Belt. Journal of Forestry. 101(3): 38-43.

Gan, J., and Kolison, Jr., S.H.1999. Minority Forest Landowners in Southeastern Alabama. Southern Journal of Applied Forestry. 23(3): 175-178.

Griffith, D.M., and Widmann, R.H. 2003. Forest Statistics for West Virginia: 1989 and 2000. Forest Inventory and Analysis Unit, Northeastern Research Station, USDA Forest Service.

Helms, J. A. 2002. What do these terms mean? Forest, Forestry, Forester. Journal of forestry 100(12): 15-19.

Henly, R.K., Ellefson, P.V., and Baughman, M.J. 1990. Minnesota’s Private Forest Management Assistance Program: An evaluation of Aspen Timber Sale Assistance. Northern Journal of Applied Forestry. 7: 31-34.

Hodges, D.G., and Cubbage, F.W. 1986. Private Forestry Consultants: 1983 Status and Accomplishments in Georgia. Southern Journal of Applied Forestry. 10: 225-230.

Hussain, A., Zhang, D., and Armstrong, J. B. 2004. Willingness to pay for Hunting Leases in Alabama. Southern Journal of Applied Forestry. 28(1): 21-27.

Jennings, B.M., McGill, D.W., Grushecky, S.T., Magill. D. J., and Lilly, D. 2004. Landowner Perspectives on Attributes of the WV FSP. Pp 271-275, In Proceedings. $14^{\text {th }}$ Central Hardwood Forest Conference;2004; Wooster, OH. Gen. Tech. Rep. NE-316. Newton Square, PA:U.S. Department of Agriculture. Forest Service. Northeastern Research Station. 539 p. [CD-ROM].

Jennings, B. 2003. Implementation of Recommended forest stewardship program practices in West Virginia: ten-year assessment. MS Thesis. West Virginia University. 68p.

Jones, S.B., Luloff, A.E., \& Finley, J.C. 1995. Another look at NIPF’s, facing our "myths". Journal of Forestry 93(9): 41-44.

Jones, S.B., \& Finley, J.C. (1993). Public forest stewardship ethic. Journal of Extension, 31(3): $8-10$. 
Kays, J.S., and Drohan, J. 2004. Forest landowner's guide to evaluating and choosing a natural resource - based enterprise. Natural Resource, Agriculture and Engineering Service (NRAES) Cooperative Extension. Ithaca. New York.

Kingsley, N.P., Brock. S.M., and DeBald, P.S. 1988. Focus Group Interviewing Applied to Retired WV NIPF Landowners. Northern Journal of Applied Forestry 5(9): 199-200.

Kronrad, Gary D. and Catherine A. Albers. 1984. Consulting forestry services and fees in North Carolina. National Woodlands, 7(1):9-12.

Kronrad, G.D., Harou, P.A.W., and Mack, R.J. 1980. Consulting Foresters’ Fees in Massachusetts. The Northern Logger and Timber Processor. 29:12-16.

Magill, D.J., McGill, D.W., Grushecky, S.T., and Jennings, B.M. 2004. Establishment, Growth, and Implementation of the Forest Stewardship Program in West Virginia. Pp 276-281, In Proceedings. $14^{\text {th }}$ Central Hardwood Forest Conference;2004; Wooster, OH. Gen. Tech. Rep. NE-316. Newton Square, PA:U.S. Department of Agriculture. Forest Service. Northeastern Research Station. 539 p. [CD-ROM].

Magill, D.J., D.W. McGill, and R. Fraser. 2004a. Refining outreach methods to Woodland Owners in West Virginia-preferred topics and delivery methods. Journal of Extension 42(4): 9p.

Magill, D. (2000). Assessing West Virginia’s NIPF owner characteristics and preferred assistance topics. Unpublished master’s thesis, West Virginia University, Morgantown, WV.

Martin, J.W. 1977. 1976 Survey of North American Forestry Consultants. The Consultant. 22(2): 58-62

McEvoy, T.J. 1998. Legal Aspects of Owning and Managing Woodlands. Island Press. Washington. D.C.

McGill, D.W., Westfall, M.3., Gartin, S.A., O’Dell, K.S., and Boone, H.N. 2004. Identifying Priority Forest Management Issues in West Virginia - A Survey of State Service Foresters. Pp 282-286. In Proceedings. $14^{\text {th }}$ Central Hardwood Forest Conference;2004; Wooster, OH. Gen. Tech. Rep. NE-316. Newton Square, PA:U.S. Department of Agriculture. Forest Service. Northeastern Research Station. 539 p. [CD-ROM].

McGill, D.W., Magill, D.J., Kochenderfer, J., Ford, W.M., and Schuler, T. 2004 a. Information transfer during the timber transaction period in West Virginia, USA. In: Communication Strategies for Multiple Partner Involvement in Forestry Extension. Proceedings of the 7th Extension Working Party Symposium. International Union of Forestry Research Organizations (IUFRO) Working Party S6.06-03 Extension, Orvietoand Rome, Italy, 27.09.-01.10.2004. 
Milliken W.F. 1988. The role of the private or consulting forester in the South's fourth forest. Miscellaneous publication - U.S. Department of Agriculture, July 1988. (1463), p. 73.

Monaghan, T.A., and Londo, A.J. 2003. Forestry terms for Mississippi Landowners. Publication 1250. Extension Service. Mississippi State University.

Munn, I.A., and Watkins, C.C. (2001). Mississippi Consultant Fees and Services: By Tract Size and Professional Affiliation. Southern Journal of Applied Forestry 25(4): 178- 186.

Olson, D.D. 1979. Realities of NIPF Ownership in Northern Michigan: An Extension Foresters' Opinion. Journal of Forestry 97(1): 17-18.

O’Hara, T.J., and Reed, A.S. 1991. Timber Market Development from Private Forests in Northwestern Minnesota. Northern Journal of Applied Forestry. 8:153-155.

Rathke, D.M., and Baughman, M.J. 1996. Influencing Non Industrial Private Forest Management through Tax System. Northern Journal of Applied Forestry. 13(1): 30-36

Royer, J.P., and Kaiser, H.F. 1985. Influence of Professional Foresters on Pine Regeneration in the South. Southern Journal of Applied Forestry. 9(1): 48-52.

Schenpf, C.C., and Baumgartner, D.M. 1988. Consulting Foresters in Pacific Northwest. West. Journal of Applied Forestry. 3(3): 74-76.

Shockley, T., and Martin, A.J. 2000. Estimating Management Plan Implementation in Northeast Wisconsin. Northern Journal of Applied Forestry. 17(4): 135-140.

Stuart, E., Jr. 1979. Association of Consulting Foresters: The First 30 Years. Journal of Forestry. 77 (8): 488-489.

United States Department of Agriculture Forest Service. 2004. Fact Sheet: West Virginia State and Private Forestry. USDA Forest Service, Northeastern Area: State and Private Forestry. (Web: http://www.na.fs.fed.us/stateadvice/zfactsheets/statefactsheets.shtm)

Weber, R. (1990). Basic content analysis. (Series Ed.) Quantitative applications in the social sciences Vol. 49. CA: Sage Publications.

Westfall, M.A. 2001. Major problems associated with the West Virginia forest sector as perceived by West Virginia Division of Forestry Service foresters. MS Thesis. West Virginia University. 80p.

West, P.C., Fly, J.M., Blahna, D.J., and Carpenter, E.M. 1988. The Communication and Diffusion of NIPF Management Strategies. Northern Journal of Applied Forestry. 5(12): 265-270. 
West Virginia GIS Technical Center (2005). http://wvgis.wvu.edu

Wicker, G. 2002. Motivations for Private Forest Landowners. Pp 225-237. In: Wear, David N.; Greis, John g., eds. 2002.Southern forest resource assessment. Gen. Tech. Rep. SRS-53. Ashville, NC, U.S. Department of Agriculture, Forest Service, Southern Research Station. 635p.

Young, R. A., M. R. Reichenbach, and F. H. Perkuhn. 1985. PNIF management: socialpsychological study of owners in Illinois. Northern Journal of Applied Forestry 2:91-94.

Zhang, D., Warren, S., and Bailey, C. 1998. The role of Assistance foresters in the NonIndustrial Private Forest management: Alabama landowners’ perspectives. Southern Journal of Applied Forestry. 22 (2): 101-105.

Zhang, D., and Mehmood, S.R. 2001. Predicting Non-Industrial Private Forest Landowners' Choices of a Forester for Harvesting and Tree Planting Assistance in Alabama. Southern Journal of Applied Forestry. 25 (3): 101-107. 


\section{APPENDICES}




\section{W WestVirginiaUniversity}

Davis College of Agriculture, Forestry and Consumer Sciences

July 11,2005 .

Dear Consulting Forester,

We are conducting a survey of the services offered and the fee structure of consulting foresters in West Virginia. Many private landowners are unaware of these fees and services; this survey is part of a research project designed to give forestland owners a general idea of the types of services available and about how much they might expect to pay for these.

Our intent in this survey is to contact the individuals of consulting firms who negotiate fees for forestry services. In the coming months, we will be conducting a follow-up survey of all foresters in West Virginia, including those with duties other than those providing direct technical assistance on private or industrial forest properties.

We hope that you will respond to the survey at your earliest convenience. Your participation is voluntary and you do not have to answer all of the questions. If you do not wish to answer the questionnaire, please let us know by returning the enclosed questionnaire blank or with a note in the self-addressed, stamped envelope.

Information you provide is strictly confidential and only summarized results describing the range of fees will be made public (for e.g., average fees charged). For information regarding your rights as a research subject, you may contact the Office of Research Compliance at 304-293-7073. If you have any questions regarding the survey, please feel free to contact us. Thank you very much for your help with this important study.

Sincerely,

Kathryn Arano, Ph.D. Assistant ProfessorForest Economics

Phone: 304-293-2941 X 2423

Email: Kathryn.Arano@mail.wvu.edu
David W. McGill, Ph.D.

Extension Specialist -

Forest Resources Management

304-293-2941 X 2474

dmcgill@wvu.edu

A WVU IRB approved copy of this letter is on file.

Phone: 304-293-294

Fax: 304-293-2441 wow forestry caf wu edu
Division of Forestry

322 Percival Hal

Morgantown un 26506-6125 


\section{W- WestVirginiaUniversity \\ Davis College of Agriculture, Forestry and Consumer Sciences}

July 27,2005

Dear Consulting Forester,

Two weeks ago a survey was mailed to you seeking information on forestry services and associated fees offered by your consulting firm. Since many private forest landowners in West Virginia are unaware of these fees and services, the survey will provide them a general idea of the types of forestry services available and about how much they might expect to pay for these.

If you have already completed and returned the survey, please accept our sincere thanks. If not, please do so at your earliest convenience. Your participation in this research project is completely voluntary and you do not have to answer all of the questions, but information you provide is vital to the success of the study. If you do not wish to answer the questionnaire, please let us know by returning the enclosed questionnaire blank or with a note in the self-addressed, stamped envelope.

Again, information you provide is strictly confidential and only summarized results describing the range of fees will be made public (for e.g., average fees charged). For information regarding your rights as a research subject, you may contact the Office of Research Compliance at 304-293-7073.

In the event you did not receive the survey questionnaire or if it has been misplaced, please contact us at 304-293-2941 x 2423 so that we can send you another one. Your contribution to the success of this study will be greatly appreciated.

Sincerely,

Kathryn G. Arano, Ph.D.

Assistant Professor -

Forest Economics
David W. McGill, Ph.D.

Extension Specialist -

Forest Resources Management

A WVU IRB Approved copy of this letter is on file. 


\section{WestVirginiaUniversity}

Davis College of Agriculture, Forestry and Consumer Sciences

August 16, 2005

Dear Consulting Forester,

About a month ago, we sent a questionnaire to your firm requesting information about your forestry services and associated fees. To the best of our knowledge, it has not been returned.

The results that we received from those who responded are demonstrating a wide range of services and fees of consulting foresters and describe some of the issues facing this important industry in West Virginia. While these initial results offer useful information, your response to the survey is extremely important to more accurately define this range of various consulting activities and to give private forest landowners a more complete picture of the forestry consulting industry in the State.

We hope that you will fill out and return the enclosed questionnaire soon. Your participation in this research project is completely voluntary and you do not have to answer all of the questions. If you are already retired from the consulting business or if for any other reason you prefer not to answer it, please let us know by returning the enclosed questionnaire blank or with a note in the self-addressed, stamped envelope.

Again, information you provide is strictly confidential and only summarized results describing the range of fees will be made public (e.g., average fees charged). For information regarding your rights as a research subject, you may contact the Office of Research Compliance at 304-293-7073.

We sincerely appreciate your help with this research project.

Sincerely,

Kathryn G. Arano, Ph.D.

Assistant Professor -

Forest Economics

Phone: 304-293-2941 X 2423

Email: Kathryn.Arano@mail.wvu.edu
David W. McGill, Ph.D.

Extension Specialist -

Forest Resources Management

304-293-2941 X 2474

dmcgill@wvu.edu 
Appendix B:

Questionnaire

\section{Fees and Services of Consulting Foresters in West Virginia}

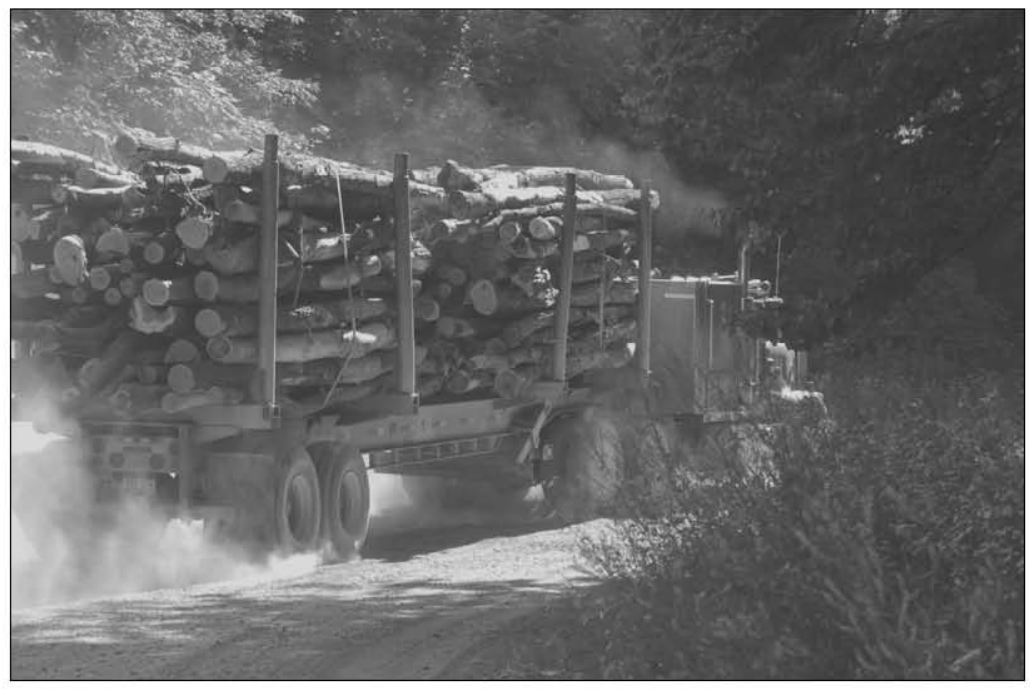

July 2005

Sponsored by:

West Virginia University

Appalachian Hardwood Center-

Extension Service/Division of Forestry 


\section{Questionnaire}

(Please check the appropriate boxes and fill the required blanks)

1. Does your firm offer forestry services? $\quad \square$ Yes $\quad \square$ No If NO, please return the survey. If $\underline{\text { YES}}$, please answer the following questions.

2. What is your role/title?

3. How many foresters work for your firm?

4. On an average how many clients are you engaged with, each year?

5. How do most clients hear about your firm?

$\begin{array}{lll}\begin{array}{l}\text { Newspaper ads___ \% } \\ \text { Radio or TV ads___ } \% \\ \text { Other }\end{array} & \begin{array}{l}\text { Pamphlets____ } \\ \text { Referrals___ } \%\end{array} & \begin{array}{l}\text { Posters/Billboards__low Pages ___ } \\ \text { Yellow }\end{array}\end{array}$

6. How many hours per month does your firm spend with pro bono work (for example, free information, advice, or visitations to a landowner before implementation of any practice)? hours.

7. List three counties in West Virginia where most of your work is conducted.

a.

b.

c.

8. Typically how far from your office are you willing to travel to do a consulting job? miles (or) hours (Circle One)

9. What is your minimum acreage requirement for your firm to consider a consulting job? acres

10. Do you have a liability insurance policy for your forestry business?

$\square$ Yes $\square$ No

11. Please describe your company:

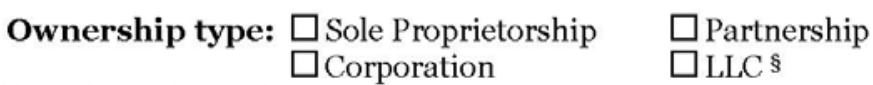

Number of employees

Organizations affiliations

Licenses/Certifications

How many years in business?

§ LLC - Limited Liability Company 
12. What percentage of your work is performed for the following client types?

$\begin{array}{lr}\text { Small NIPFs (<100 acres) } & \% \\ \text { Large NIPFs (>=100 acres) } & \% \\ \text { Industry } & \% \\ \text { Trust/Estates } & \% \\ \text { Financial Institution } & \% \\ \text { Government } & \\ \text { Other Investors } & \\ \text { Other } & \end{array}$

13. What are the two biggest challenges facing your company today?

A.

B.

Following are questions related to the different services offered and average fees charged for each service. Based on the type of fees you charge, fill in average amounts, approximate number of jobs, and average acres your company has completed per year. 


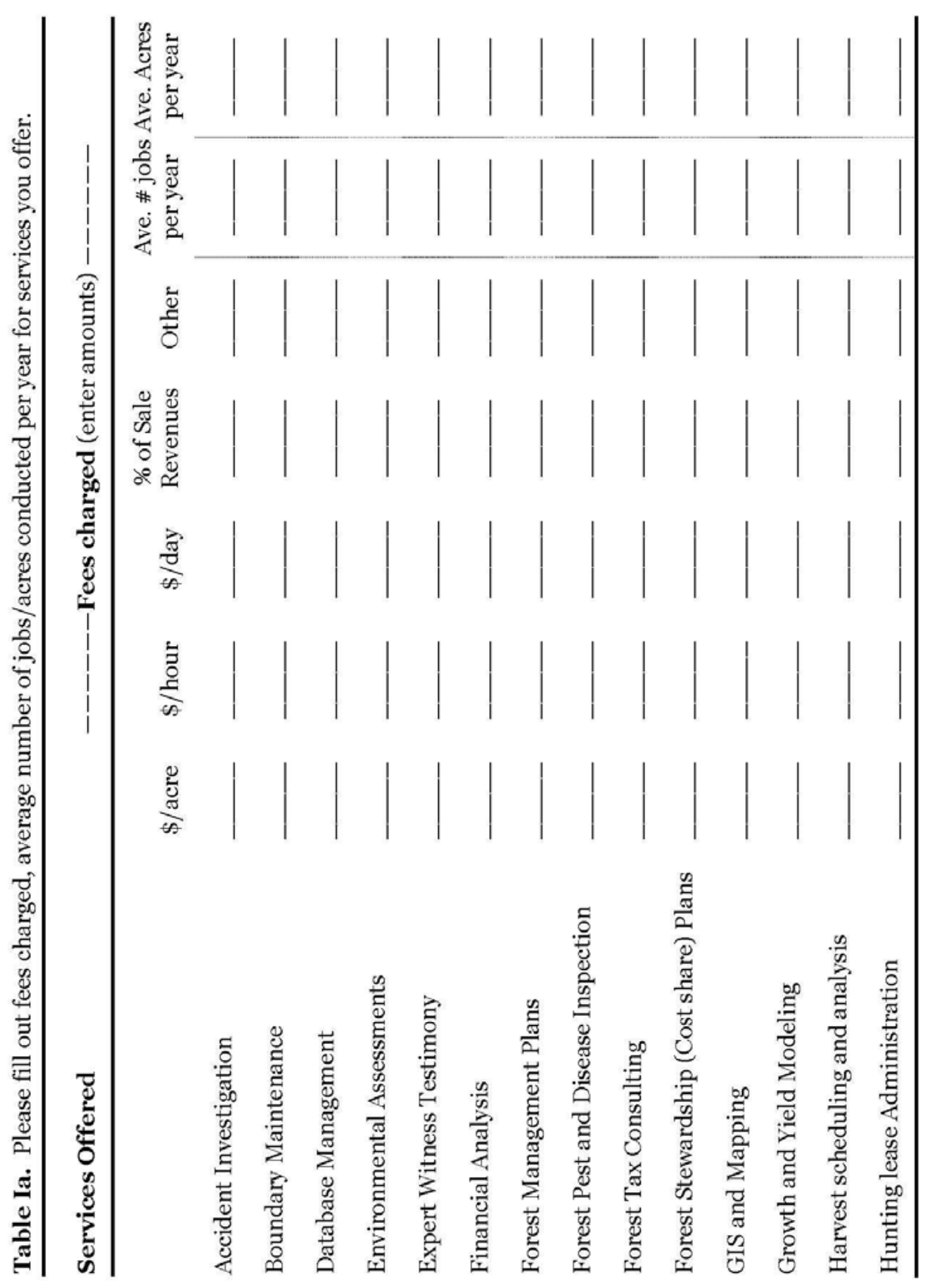




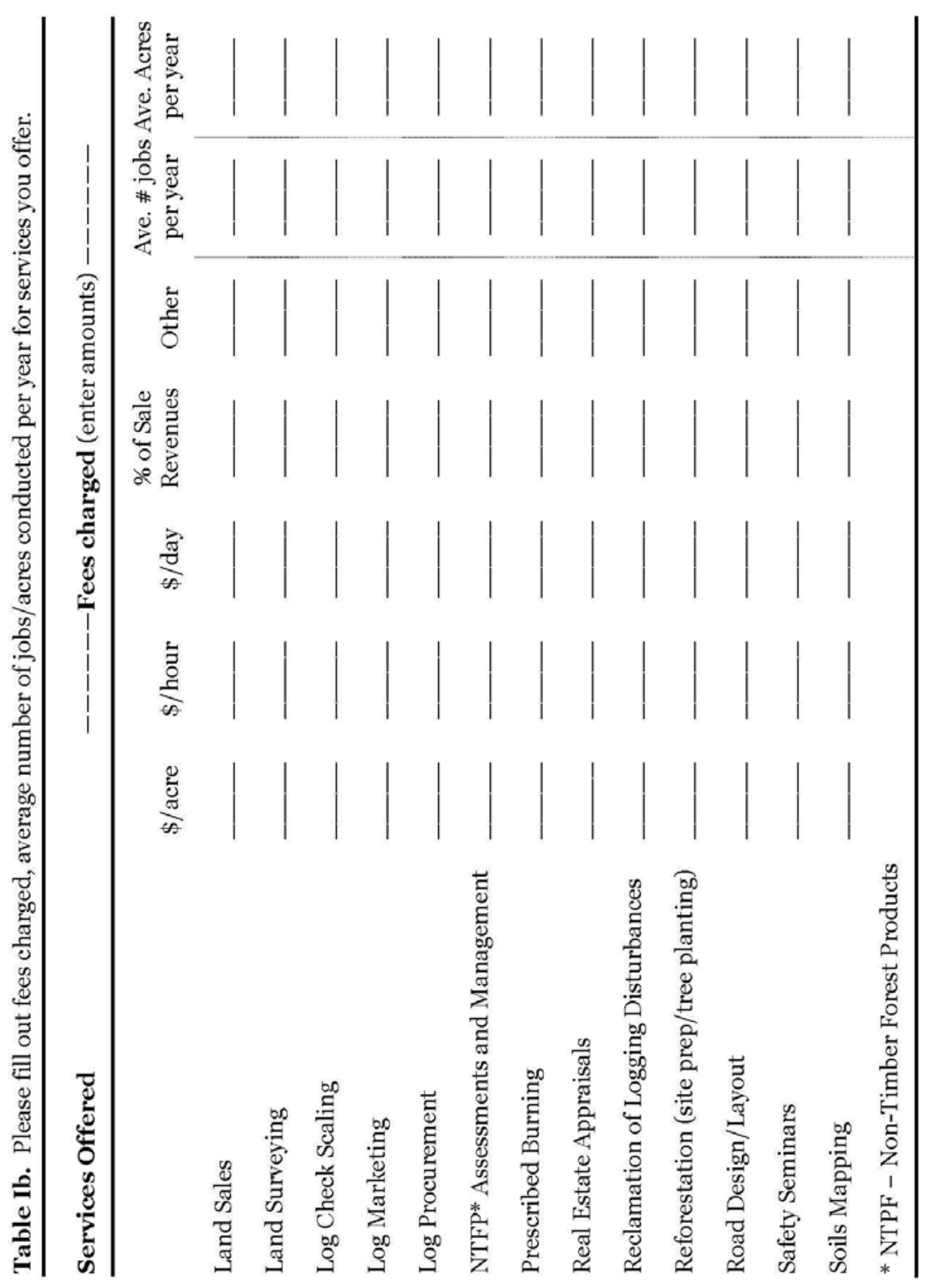




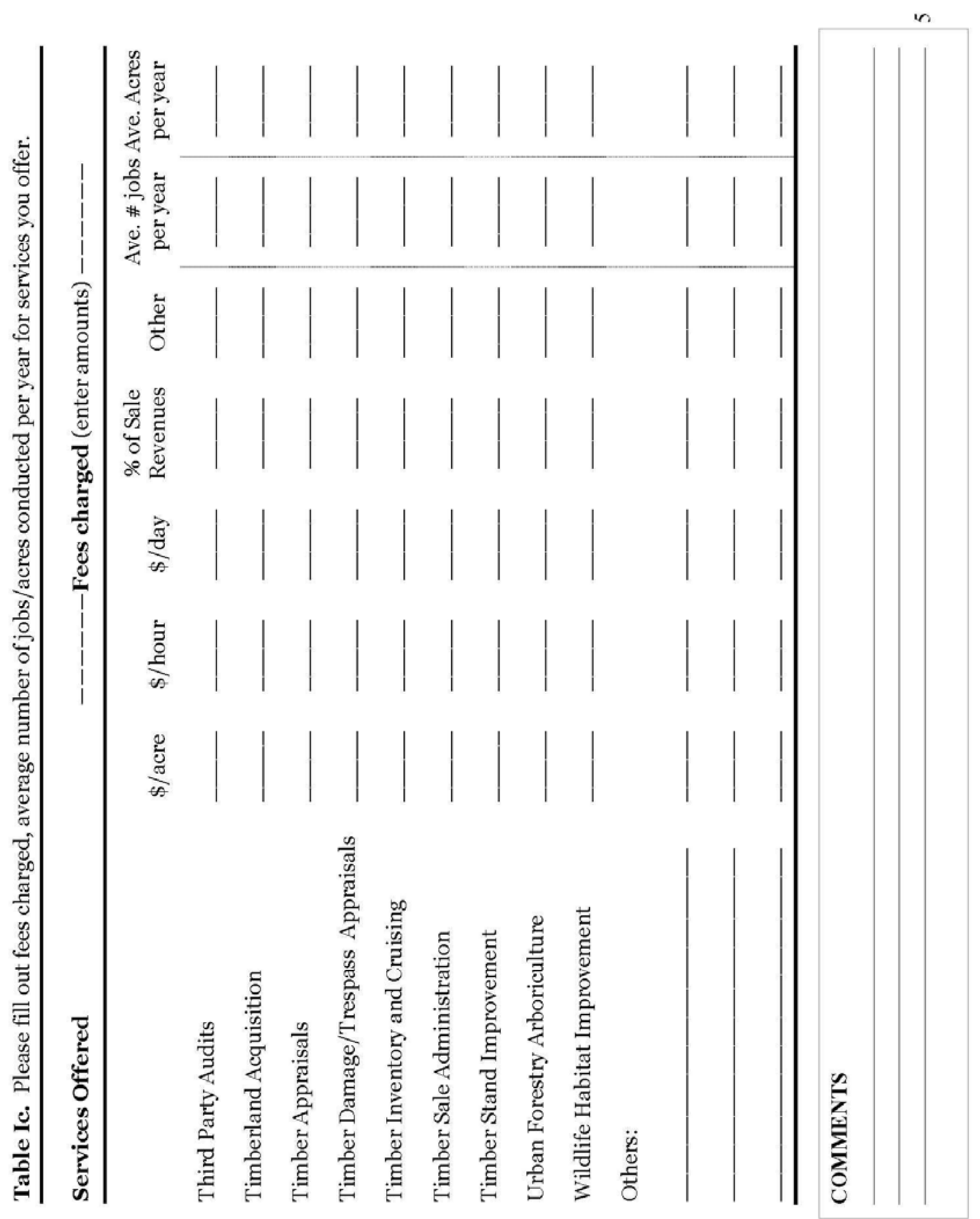


Appendix C: Fees charged by the consultants for various services in West Virginia, 2005.

\begin{tabular}{|c|c|c|c|c|c|}
\hline Services Offered & $\mathrm{n}^{1}$ & Unit & Min. & Mean & Max. \\
\hline Accident Investigation & 6 & \$/hour & 20 & 64.17 & 125 \\
\hline \multirow[t]{2}{*}{ Boundary Maintenance } & 15 & \$/hour & 20 & 45.20 & 100 \\
\hline & 5 & \$/day & 200 & 326.00 & 480 \\
\hline Database Management & 6 & \$/hour & 20 & 42.50 & 70 \\
\hline \multirow[t]{2}{*}{ Environmental Assessments } & 7 & \$/hour & 20 & 42.14 & 80 \\
\hline & 2 & \$/day & 300 & 325.00 & 350 \\
\hline \multirow[t]{2}{*}{ Expert Witness Testimony } & 25 & \$/hour & 20 & 72.00 & 200 \\
\hline & 8 & \$/day & 250 & 430.00 & 640 \\
\hline \multirow[t]{2}{*}{ Financial Analysis } & 8 & \$/hour & 20 & 50.63 & 100 \\
\hline & 4 & \$/day & 300 & 342.50 & 400 \\
\hline \multirow[t]{3}{*}{ Forest Management Plans } & 12 & \$/acre & 4.75 & 6.07 & 7.00 \\
\hline & 14 & \$/hour & 20 & 37.86 & 60 \\
\hline & 9 & \$/day & 200 & 315.56 & 480 \\
\hline \multirow[t]{2}{*}{ Forest Pest and Disease Inspection } & 9 & \$/hour & 20 & 42.78 & 70 \\
\hline & 4 & \$/day & 300 & 342.50 & 400 \\
\hline \multirow[t]{3}{*}{ Forest Stewardship (Cost share) Plans } & 15 & \$/acre & 4 & 5.47 & 7 \\
\hline & 4 & \$/hour & 20 & 43.75 & 60 \\
\hline & 3 & \$/day & 240 & 373.33 & 480 \\
\hline \multirow[t]{2}{*}{ Forest Tax Consulting } & 7 & \$/hour & 20 & 45.71 & 60 \\
\hline & 2 & \$/day & 300 & 325.00 & 350 \\
\hline \multirow[t]{3}{*}{ GIS and Mapping } & 1 & $\$$ /acre & - & 5.50 & \\
\hline & 9 & \$/hour & 20 & 46.67 & 75 \\
\hline & 2 & \$/day & 325 & 402.50 & 480 \\
\hline \multirow[t]{2}{*}{ Growth and Yield Modeling } & 7 & \$/hour & 20 & 45.71 & 60 \\
\hline & 1 & \$/day & - & 300.00 & - \\
\hline \multirow[t]{2}{*}{ Harvest scheduling and analysis } & 10 & \$/hour & 20 & 41.50 & 75 \\
\hline & 4 & \$/day & 300 & 355.00 & 400 \\
\hline \multirow[t]{2}{*}{ Hunting lease Administration } & 8 & \$/hour & 5 & 38.75 & 60 \\
\hline & 3 & \$/day & 300 & 333.33 & 350 \\
\hline
\end{tabular}




\begin{tabular}{|c|c|c|c|c|c|}
\hline & 2 & $\%$ of Sale & 1 & 6.5 & 12 \\
\hline \multirow{3}{*}{ Land Sales } & 5 & \$/hour & 20 & 40.00 & 50 \\
\hline & 2 & \$/day & 320 & 360.00 & 400 \\
\hline & 7 & $\%$ of Sale & 5 & 15 & 50 \\
\hline \multirow[t]{2}{*}{ Land Surveying } & 3 & \$/hour & 50 & 68.33 & 80 \\
\hline & 2 & \$/day & 600 & 620.00 & 640 \\
\hline \multirow{2}{*}{ Log Check Scaling } & 6 & \$/hour & 40 & 48.33 & 60 \\
\hline & 1 & $\$ /$ day & - & 320.00 & \\
\hline \multirow[t]{3}{*}{ Log Marketing } & 5 & \$/hour & 40 & 43.00 & 50 \\
\hline & 1 & \$/day & - & 320.00 & - \\
\hline & 2 & $\%$ of Sale & - & 10 & \\
\hline \multirow[t]{3}{*}{ Log Procurement } & 2 & $\$ /$ hour & 40 & 45.00 & 50 \\
\hline & 1 & $\$ /$ day & - & 320.00 & \\
\hline & 1 & $\%$ of Sale & - & 10 & \\
\hline \multirow{3}{*}{ NTFP* Assessments and Management } & 3 & \$/hour & 20 & 36.70 & 50 \\
\hline & 2 & \$/day & 320 & 335.00 & 350 \\
\hline & 3 & $\%$ of Sale & 1 & 13.67 & 30 \\
\hline Prescribed Burning & 2 & $\$ /$ hour & 45 & 47.50 & 50 \\
\hline \multirow[t]{3}{*}{ Real Estate Appraisals } & 2 & \$/acre & 5 & 15.00 & 25 \\
\hline & 9 & \$/hour & 20 & 59.44 & 100 \\
\hline & 2 & \$/day & 400 & 520.00 & 640 \\
\hline \multirow[t]{2}{*}{ Reclamation of Logging Disturbances } & 4 & $\$ /$ hour & 30 & 37.50 & 50 \\
\hline & 2 & \$/day & - & 400.00 & . \\
\hline \multirow[t]{3}{*}{ Reforestation (site prep/tree planting) } & 1 & \$/acre & - & 150.00 & - \\
\hline & 2 & \$/hour & 40 & 42.50 & 45 \\
\hline & 1 & \$/day & - & 300.00 & \\
\hline \multirow[t]{2}{*}{ Road Design/Layout } & 13 & $\$ /$ hour & 20 & 45.38 & 100 \\
\hline & 4 & \$/day & 320 & 440.00 & 640 \\
\hline \multirow{2}{*}{ Safety Seminars } & 3 & \$/hour & 40 & 53.33 & 70 \\
\hline & 1 & \$/day & - & 320.00 & \\
\hline Soils Mapping & 4 & $\$ /$ hour & 30 & 38.75 & 50 \\
\hline Third Party Audits & 4 & \$/hour & 40 & 43.75 & 50 \\
\hline
\end{tabular}




\begin{tabular}{|c|c|c|c|c|c|}
\hline & 1 & \$/day & - & 320.00 & - \\
\hline \multirow[t]{4}{*}{ Timberland Acquisition } & 2 & \$/acre & 10 & 130.00 & 250 \\
\hline & 10 & \$/hour & 25 & 46.50 & 80 \\
\hline & 4 & \$/day & 320 & 427.50 & 640 \\
\hline & 3 & $\%$ of Sale & 5 & 8.33 & 10 \\
\hline \multirow[t]{4}{*}{ Timber Appraisals } & 5 & \$/acre & 5 & 5.90 & 7 \\
\hline & 20 & \$/hour & 20 & 44.50 & 80 \\
\hline & 13 & \$/day & 200 & 338.46 & 640 \\
\hline & 8 & $\%$ of Sale & 1 & 10.75 & 20 \\
\hline \multirow[t]{3}{*}{ Timber Damage/Trespass Appraisals } & 23 & \$/hour & 20 & 48.04 & 125 \\
\hline & 9 & \$/day & 240 & 328.89 & 500 \\
\hline & 5 & $\%$ of Sale & 1 & 4.8 & 10 \\
\hline \multirow[t]{3}{*}{ Timber Inventory and Cruising } & 5 & \$/acre & 3 & 4.80 & 6 \\
\hline & 16 & \$/hour & 20 & 42.50 & 70 \\
\hline & 13 & $\$ /$ day & 150 & 296.92 & 450 \\
\hline \multirow[t]{3}{*}{ Timber Sale Administration } & 10 & \$/hour & 20 & 45.50 & 80 \\
\hline & 4 & \$/day & 240 & 387.50 & 640 \\
\hline & 35 & $\%$ of Sale & 8 & 11.71 & 30 \\
\hline \multirow[t]{3}{*}{ Timber Stand Improvement } & 1 & \$/acre & - & 150.00 & - \\
\hline & 6 & \$/hour & 20 & 40.00 & 70 \\
\hline & 3 & \$/day & 240 & 296.67 & 350 \\
\hline Urban Forestry Arboriculture & - & \$/hour & - & - & - \\
\hline \multirow[t]{2}{*}{ Wildlife Habitat Improvement } & 4 & \$/hour & 20 & 33.75 & 45 \\
\hline & 4 & $\$ /$ day & 300 & 350.00 & 400 \\
\hline \multirow{3}{*}{$\begin{array}{l}\text { Others }^{2} \\
\text { Invasive plant Analysis }\end{array}$} & & & & & \\
\hline & 1 & $\$ /$ day & - & 350.00 & - \\
\hline & 1 & $\%$ of Sale & - & 1 & . \\
\hline Timber Marketing (Hired out) & 1 & $\$ /$ day & - & 150.00 & - \\
\hline \multirow[t]{2}{*}{ Gas well site approval } & 1 & $\$ /$ hour & - & 45.00 & - \\
\hline & 1 & $\%$ of Sale & - & 10 & . \\
\hline HW lumber inspection & 1 & \$/day & - & 240.00 & - \\
\hline Timber damage and oil/gas development & 1 & $\$ /$ hour & - & 30.00 & - \\
\hline Routine property visits (absentee) & 1 & $\$ /$ hour & - & 30.00 & - \\
\hline
\end{tabular}


\begin{tabular}{lllll} 
Oil and gas environmental consulting & 1 & $\$$ & 30.00 \\
\hline
\end{tabular}

- Number of consultants offering the service.

2 - Others were filled in by the respondents 